Article

\title{
Surface-Modified Industrial Acrylonitrile Butadiene Styrene 3D Scaffold Fabrication by Gold Nanoparticle for Drug Screening
}

\author{
Kaudjhis Patrick Ulrich N'deh ${ }^{1,2, \dagger}$, Gyeong-Ji Kim ${ }^{2,3, \dagger}$, Kang-Hyun Chung ${ }^{1}$, Jae-Soo Shin ${ }^{4}$, \\ Kwang-Sup Lee ${ }^{5}$, Jeong-Woo Choi ${ }^{3,6}$, Kwon-Jai Lee ${ }^{7, *}$ and Jeung Hee An ${ }^{2, *}$ (D) \\ 1 Department of Food Science and Technology, Seoul National University of Science \& Technology, \\ Seoul 01811, Korea; kaudjhispatrick@gmail.com (K.P.U.N.); carl@seoultech.ac.kr (K.-H.C) \\ 2 Department of Food Science and Nutrition, KC University, Seoul 07661, Korea; kgj8495@hanmail.net \\ 3 Department of Biomedical Engineering, Sogang University, Seoul 04107, Korea \\ Department of Advanced Materials Engineering, Daejeon University, Daejon 34520, Korea; jsshin@dju.ac.kr \\ 5 Department of Advanced Materials, Hannam University, Daejeon 34520, Korea; kslee@hnu.kr \\ 6 Department of Chemical and Biomolecular Engineering, Sogang University, Seoul 04107, Korea; \\ jwchoi@sogang.ac.kr \\ 7 Department of H-LAC, Daejeon University, Daejon 34520, Korea \\ * Correspondence: kjlee@dju.kr (K.-J.L.); anjhee@hanmail.net (J.H.A.); Tel.: +82-42-280-1217 (K.-J.L.); \\ +82-2-2600-2566 (J.H.A.) \\ + These authors contributed equally to this work.
}

Received: 19 February 2020; Accepted: 12 March 2020; Published: 15 March 2020

\begin{abstract}
Biocompatibility is very important for cell growth using 3D printers, but biocompatibility materials are very expensive. In this study, we investigated the possibility of cell culture by the surface modification of relatively low-cost industrial materials and an efficient three-dimensional (3D) scaffold made with an industrial ABS filament for cell proliferation, spheroid formation, and drug screening applications. We evaluated the adequate structure among two-layer square shape 3D scaffolds printed by fused deposition modeling with variable infill densities (10-50\%). Based on the effects of these scaffolds on cell proliferation and spheroid formation, we conducted experiments using the industrial ABS 3D scaffold (IA3D) with $40 \%$ of infill density, which presented an external dimension of $(\mathrm{XYZ}) 7650 \mu \mathrm{m} \times 7647 \mu \mathrm{m} \times 210 \mu \mathrm{m}, 29.8 \%$ porosity, and 225 homogenous micropores $(251.6 \mu \mathrm{m} \times 245.9 \mu \mathrm{m} \times 210 \mu \mathrm{m})$. In the IA3D, spheroids of cancer HepG2 cells and keratinocytes $\mathrm{HaCaT}$ cells appeared after 2 and 3 days of culture, respectively, whereas no spheroids were formed in 2D culture. A gold nanoparticle-coated industrial ABS 3D scaffold (GIA3D) exhibited enhanced biocompatible properties including increased spheroid formation by HepG2 cells compared to IA3D (1.3-fold) and 2D (38-fold) cultures. Furthermore, the cancer cells exhibited increased resistance to drug treatments in GIA3D, with cell viabilities of $122.9 \%$ in industrial GIA3D, $40.2 \%$ in IA3D, and $55.2 \%$ in $2 \mathrm{D}$ cultures when treated with $100 \mu \mathrm{M}$ of mitoxantrone. Our results show that the newly engineered IA3D is an innovative 3D scaffold with upgraded properties for cell proliferation, spheroid formation, and drug-screening applications.
\end{abstract}

Keywords: 3D cell culture; industrial ABS scaffolds; gold nanoparticles; cancer cells; skin cells

\section{Introduction}

Scaffold-based three-dimensional (3D) cell cultures are important technologies with numerous applications in drug development, tissue engineering, and regenerative medicine [1,2]. These innovative biomaterials have brought advances to and broaden the possibilities of cellular and molecular biology. 
The microenvironment offered by 3D scaffolds promotes cells adhesion to the extracellular matrix, cell-to-cell interaction, cell growth in 3D shapes, and cell differentiation [3,4]. The main advantage of 3D scaffolds is to reproduce reliable in vitro models able to mimic the in vivo conditions for tissue engineering and new drug development applications [1]. Nowadays, the development of modern drugs requires the implementation and validation of a wide range of preclinical tests and protocols that are costly and time-consuming [5]. A usual process of preclinical drug testing requires both cell and animal experiments. Unfortunately, the traditional in vitro two-dimensional (2D) cell cultures poorly recapitulate the in vivo environment and have many limitations, including an altered cell morphology, polarity, phenotypes, and division mode in cells, as well as a disturbance of cell-to-cell and cell-to-extracellular environment interactions [6]. Since these models are better suited for understanding the overall effects of an experiment on a living subject [7], these models often make it difficult to understand the drug-specific mode of action [8]. Three-dimensional models such as 3D scaffolds better mimic the in vivo conditions for cell studies, tissue organization, and drug screening applications, by comparison to conventional 2D models. Therefore, they can be considered as potent alternatives to animal testing. Several materials are used in 3D scaffolds printing [9-14].

The biocompatible materials commonly used in 3D scaffold printing are polylactic acid (PLA), polyglycolic acid (PGA), polycaprolactone (PCL), and polyethylene glycol (PEG) [9]. Alternatively, the most commonly used materials by 3D printers are PLA and acrylonitrile butadiene styrene (ABS) [9]. For biological applications, the thermoplastic bio-ABS material type has been used to create ear-shaped molds for human skin cell culture and to create tympanic membranes using bovine articular chondrocytes $[10,11]$. In addition, the biocompatible material ABS-M30i has been used to create a new generation of biocompatible and biomimetic implants, which can be used for the replacement of not only bone segments but also entire bones [12]. However, apart from ABS-M30i, which is suitable for biotechnological applications, industrial ABS is known to be non-biodegradable and non-biocompatible [9]. Various polymers, such as PLA, PCL, PEG, and ABS have been used in 3D scaffold fabrication for cell culture and tissue engineering applications. However, industrial ABS has not been evaluated with respect to its biocompatibility or toxicity.

We printed a 3D scaffold using industrial ABS material and coated that structure with gold nanoparticles (Au-NPs) to increase the cellular safety of the industrial ABS material. According to a recent study, the development of 3D nanocomposite materials with incorporated nanoparticles has attracted interest, as nano-sized particles offer the potential to enhance various properties of the 3D-printed parts $[13,14]$. Au-NPs are widely used in biological research, particularly in cell-based assays, due to their biocompatibility, unique surface plasmon, optical and catalytic properties, high chemical stability, suitable surface functionality, ease of functionalization, and increased mechanical properties $[15,16]$. $\mathrm{Au}-\mathrm{NPs}$ have been incorporated into macroporous scaffolds to increase matrix conductivity and to promote cell adhesion, growth, differentiation, maturation, and morphogenesis [15-19].

In this study, we investigated a low-cost industrial ABS 3D scaffold (IA3D) printed by fused deposition modeling for cell proliferation, spheroid formation, and drug screening. To improve the biocompatible properties of the industrial ABS material, Au-NPs were coated on the IA3D. Our result is the first report of a gold nanoparticle-coated industrial ABS scaffold (GIA3D), which can be easily employed to stimulate cell viability and proliferation in vitro, as well as to mimic the in vivo conditions for drug testing.

\section{Materials and Methods}

\subsection{Fabrication and Characterization of $I A 3 D$}

The fabrication of the IA3D is schematically presented in Figure 1. Briefly, the two-layer 3D scaffold with a square shape pattern $(X Y Z)(8 \mathrm{~mm} \times 8 \mathrm{~mm} \times 0.2 \mathrm{~mm})$ was produced using the computer-aided design (CAD) software NewCreatork (version 1.57.41) and printed in a $60-\mathrm{mm}$ format petri dish using a fused deposition modeling (FDM) technique with a 3D bioprinter (Rokit In vivo, Seoul, Korea). 
The optimal position of the petri dish was selected on a XYZ piezoelectric stage under the $200 \mu \mathrm{m}$ extruder nozzle. Subsequently, the IA3D white filament $(1.75 \mathrm{~mm})$ acquired from 3D KNT (Seoul, Korea) was inserted into the extruder feed throat and printed by extrusion at $250{ }^{\circ} \mathrm{C}$ in the petri dish. The main printing parameter was the infill density. In the FDM technique, the infill density determines the amount of material that is filled into an object [20]. Modifications in the infill density parameter alter 3D printed structures, leading to printed objects with various porosities [9]. IA3D with 10\%, 20\%, $30 \%, 40 \%$, and 50\% infill densities were printed within $2 \mathrm{~min}$ with printing speed set to $5 \mathrm{~mm} / \mathrm{s}$ and filament input flow fixed to $200 \%$.

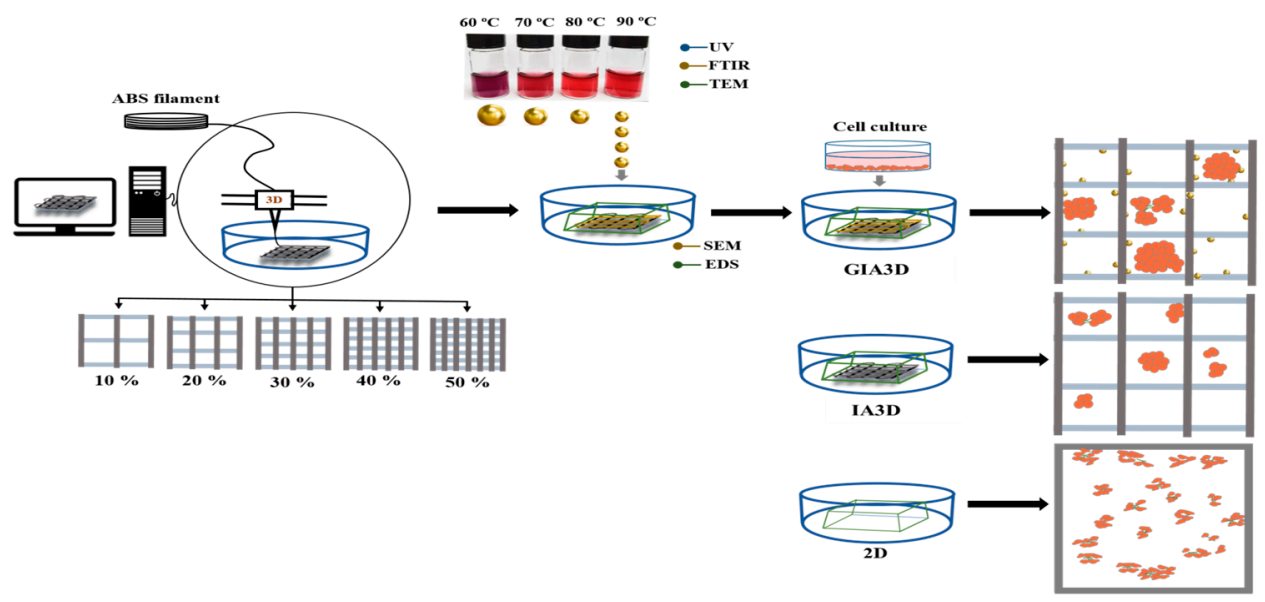

Figure 1. Schematic diagram of the experimental method. The 3D scaffold patterns were designed using a computer with NewCreatork program (version 1.57.41) for 3D printers. Industrial acrylonitrile butadiene styrene (ABS) white filament $(1.75 \mathrm{~mm})$ was inserted in the extruder feed throat of a 3D bioprinter and heated at $250{ }^{\circ} \mathrm{C}$ in the chamber. The scaffold was printed layer-by-layer via the fused deposition modeling technique into a $60-\mathrm{mm}$ format Petri dish. A 3D culture microenvironment was created by fixing a miniature plastic chamber (XYZ approximately $1 \mathrm{~cm} \times 1 \mathrm{~cm} \times 1 \mathrm{~cm}$ ) around the scaffold, in which gold nanoparticles (Au-NPs) were chemically synthesized and coated on the scaffold's structure by deposition. The synthesis of Au-NPs was realized by the reduction of $\mathrm{Au}^{3+}$ ions from gold (III) chloride with the citrate from trisodium citrate at high temperature $\left(60^{\circ} \mathrm{C}\right.$ to $\left.90{ }^{\circ} \mathrm{C}\right)$ for 60 min of reaction. Finally, the cancer model HepG2 and keratinocyte HaCaT cells were cultured in 3D (with/without Au-NPs) and 2D culture systems (same size miniature plastic chamber was fixed on the flat surface of petri dish).

The morphology and microstructure of the scaffolds was visualized under an optical microscope (Nikon Eclipse TS100led Trinocular) equipped with a digital camera and with scanning electron microscope (SEM) (ZEISS GEMINI2, Oberkochen, Germany). The approximate average dimensions of rectangular pores $(X Y)$ for each scaffold group were calculated from the images made by the optical microscope via ImageJ software (NIH 1.51a), $(n \geq 5)$ [21]. The scaffold porosity (in volume \%) was measured using the following equation [22]:

$$
\text { Porosity }(\%)=\frac{V-\left(\frac{M}{\rho}\right)}{V} \times 100 \%,
$$

where $V$ is the volume of the scaffold calculated using its outer dimension, $M$ is the mass of the porous scaffold, and $\rho$ is the density of IA3D $\left(1.04 \mathrm{~g} / \mathrm{cm}^{3}\right)$. Five scaffolds per infill density type were dried overnight at $80^{\circ} \mathrm{C}$ and weighed $(M)$. Then, the porosity of scaffold was calculated using Equation (1).

\subsection{Au-NPs Synthesis, Characterization, and Surface Modification of Scaffold}

To enhance the biocompatibility of IA3D, Au-NPs were coated onto IA3D by deposition. First, a miniature plastic chamber system, approximately (XYZ) $1 \mathrm{~cm} \times 1 \mathrm{~cm} \times 1 \mathrm{~cm}$ (Lab-Tek chamber 
177402, Thermo Fisher Scientific Inc, Rochester, NY, USA) was fixed around the printed scaffold with polydimethylsiloxane. Subsequently, Au-NPs were synthesized in the plastic chamber via a chemical method modified from Turkevich and Frens 1951, 1973 [23-25]. The reduction of auric ions $\left(\mathrm{Au}^{3+}\right)$ from chloroauric acid trihydrate $\left(\mathrm{HAuCl}_{4} \cdot 3 \mathrm{H}_{2} \mathrm{O}\right)($ Kojima Chemicals, Japan) was initiated by the citrate from trisodium citrate dihydrate salt $\left(\mathrm{C}_{6} \mathrm{H}_{5} \mathrm{Na}_{3} \mathrm{O}_{7} \cdot 2 \mathrm{H}_{2} \mathrm{O}\right)$ (Samchun Pure Chemicals, Pyeongtaek, Korea). Briefly, in the miniature plastic chamber, a $500 \mu \mathrm{L}$ solution containing $0.25 \mathrm{mM}$ of $\mathrm{Au}^{3+}$ and $1.5 \mathrm{mM}$ of citrate (1:6) was prepared by diluting the corresponding salts in deionized water. Then, the mixture was stirred at $50 \mathrm{rpm}$ on an orbital shaker for $5 \mathrm{~min}$, and scaffolds were incubated in a preheated (approximately $35^{\circ} \mathrm{C}$ ) dry oven (SW-DO002, Gimhae, Seoul, Korea) at high temperature $\left(60^{\circ} \mathrm{C}, 70{ }^{\circ} \mathrm{C}\right.$, $80^{\circ} \mathrm{C}$, or $90^{\circ} \mathrm{C}$ ) for $60 \mathrm{~min}$. Finally, scaffolds were cooled to $36^{\circ} \mathrm{C}$ in the oven and then extracted. Synthesized Au-NPs coated the surface of IA3D by deposition, whereas the Au-NPs remaining in colloidal solution were stored in glass vials protected from light for further analysis, including UV-vis, Fourier-transform infrared spectroscopy (FTIR), and transmission electron microscopy (TEM).

The UV-vis transmittance spectra of Au-NPs in colloidal solutions synthesized at $60^{\circ} \mathrm{C}, 70^{\circ} \mathrm{C}$, $80^{\circ} \mathrm{C}$, and $90^{\circ} \mathrm{C}$ were recorded in the range between 380 and $780 \mathrm{~nm}$ using a Shimadzu UV mini-1240 spectrophotometer (Kyoto, Japan) in a 1-cm glass cuvette. The FTIR spectra of Au-NPs solution synthesized at $90{ }^{\circ} \mathrm{C}$ and trisodium citrate solution $(88 \mathrm{~g} / \mathrm{L})$ were recorded without any sample preparation using a Cary 630 FTIR spectrometer in the spectral ranging from 650 to $4000 \mathrm{~cm}^{-1}$. Then, the IR spectra were collected using Agilent MicroLab PC software (Agilent Technologies, Inc., Santa Clara, CA, USA). The size of the particles was analyzed by TEM using a Hitachi HF-2000 (Tokyo, Japan) field emission TEM operating at $200 \mathrm{kV}$. From the TEM images, the sizes of particles in different samples were determined by counting at least 100 particles. The presence of Au-NPs on the surface of the IA3D was verified by energy-dispersive X-Ray spectroscopy (EDS) analyses with SEM.

\subsection{Cell Seeding in IA3D and GIA3D}

The 3D culture microenvironments were fabricated for both the IA3D and the GIA3D by fixing the miniature plastic chamber around the scaffold's structure, as described previously in Section 2.2. Additionally, a 2D culture microenvironment was fabricated by fixing a plastic chamber of the same size on the flat surface of a Petri dish. HaCaT cells (Human keratinocyte cells) and HepG2 cells (human hepatoma cells) were obtained from the American Type Culture Collection (ATCC). Cells were cultured in Dulbecco's modified Eagle's medium (Invitrogen, Carlsbad, CA, USA) supplemented with 10\% fetal bovine serum (Hyclone, Logan, UT, USA), $200 \mathrm{mM}$ of glutamine, and $100 \mathrm{U} / \mathrm{mL}$ of penicillin in a humidified chamber with $5 \% \mathrm{CO}_{2}$ at $37^{\circ} \mathrm{C}$.

\subsection{Cell Morphology Cultured on Surface Coated with Au-NPs}

The surface morphologies and metabolic status of HepG2 and HaCaT cells on a gold nanoparticles-coated 2D plate (G2D) and GIA3D were analyzed by SEM. The SEM image was used to compare the growth of HepG2 cells (seeded at $3 \times 10^{3}$ cell $/ \mathrm{mL}$ ) and HaCaT cells (seeded at $5 \times 10^{4} \mathrm{cell} / \mathrm{mL}$ ) cultured on GIA3D and G2D at $48 \mathrm{~h}$.

\subsection{Cytotoxicity of IA3D and GIA3D}

To select the IA3D with optimum infill density, a Live/Dead cell assay kit (BioVision) was used to qualitatively assess the viability and proliferation of the HaCaT cells (seeded at $5 \times 10^{4} \mathrm{cell} / \mathrm{mL}$ ) on IA3D printed with various infill densities (10-50\%). This assay was also used to compare the growth of HepG2 (seeded at $3 \times 10^{3}$ cell $/ \mathrm{mL}$ ) cultured on either a 2D plate, IA3D, or GIA3D at 3, 5, 7, 9, and 11 days. In addition, the total spheroid population of a $72 \mathrm{~h}$ HepG2 cell culture in IA3D versus GIA3D was determined using Live/Dead cell assay. In this assay, cell cultures were treated with Live-Dye, a cell-permeable green fluorescent dye, and propidium iodide, a non-permeable red fluorescent dye. Live cells were stained with only the cell-permeable fluorescent green dye, and dead cells were stained with both the cell-permeable Live-Dye and propidium iodide. The cells were observed immediately 
under a fluorescence microscope Nikon Eclipse TS100led Trinocular (Nikon corporation, Tokyo, Japan) using a band-pass filter (detect fluorescein and rhodamine).

In addition, the viability of HepG2 cells and $\mathrm{HaCaT}$ cells in the scaffolds was determined by a EZ-Cytox cell viability assay kit (DoGenBio Co. Ltd, Seoul, Korea), which is based on the cleavage of the tetrazolium salt to water-soluble formazan by succinate-tetrazolium reductase. HepG2 cells $\left(1 \times 10^{3}, 2 \times 10^{3}\right.$, and $3 \times 10^{3}$ cells $\left./ \mathrm{mL}\right)$ and HaCaT cells $\left(8 \times 10^{3}, 1 \times 10^{4}\right.$, and $5 \times 10^{4}$ cells $\left./ \mathrm{mL}\right)$ were cultured in 2D system, IA3D, and GIA3D for 6, 24, 48, and $72 \mathrm{~h}$. Next, 10\% of EZ-Cytox reagent was added to the media and incubated for $1 \mathrm{~h}$ at $37^{\circ} \mathrm{C}$. Subsequently, $100 \mu \mathrm{L}$ of that media (in triplicate) was added per well in a 96-well plate, and absorbance was measured using micro-titer plate reader from $420-480 \mathrm{~nm}$ with a reference of $650 \mathrm{~nm}$. Blanks were used for each concentration to ensure accurate results.

\subsection{Measurement of Apoptosis}

HaCaT cells were seeded in the 2D system, IA3D, and GIA3D at a density of $5 \times 10^{4}$ cells $/ \mathrm{mL}$. Apoptotic cells were quantified using an Annexin V-FITC apoptosis detection kit (BD Biosciences, San Diego, CA, USA) according to the manufacturer's instructions.

\subsection{Immunofluorescence Staining}

HaCaT cells (seeded at $5 \times 10^{4}$ cell $/ \mathrm{mL}$ ) were plated on the GIA3D on day 3. Cells were stained using primary antibodies of F-actin and secondary antibodies labeled with Q-dot-conjugated fluorescein isothiocyanate (FITC, green; Invitrogen, Carlsbad, CA, USA). The cells were viewed and photographed using a confocal laser scanning microscope (Carl Zeiss MicroImaging, Oberkochen, Germany). The images were acquired using a confocal microscope with LSM imaging software (Carl, Zeiss, Jena, Germany).

\subsection{Drug Screening in IA3D and GIA3D}

We also measured the viability of cells intoxicated with asiatic acid 97\% (Sigma-Aldrich, Saint Louis, MO, USA) and mitoxantrone (Reyon Pharmaceutical Co., Ltd., Seoul, Korea) to compare the drug-resistance capacity of HepG2 $\left(3 \times 10^{3} \mathrm{cell} / \mathrm{mL}\right)$ and HaCaT cells $\left(5 \times 10^{4}\right.$ cell $\left./ \mathrm{mL}\right)$ between the 2D system, IA3D, and GIA3D. After $72 \mathrm{~h}$ of culture, HepG2 cells were exposed to mitoxantrone $(0,1,10$, 50 , and $100 \mu \mathrm{M})$ and asiatic acid $(0,10,75,150$, and $200 \mu \mathrm{M})$ for $24 \mathrm{~h}$, while the HaCaT were treated with mitoxantrone $(0,0.1,0.3,0.5$, and $0.8 \mu \mathrm{M})$ and asiatic acid $(0,50,100,200$, and $300 \mu \mathrm{M})$ for $24 \mathrm{~h}$. Experiments were performed in triplicate, and the cytotoxic effects of the drugs were measured using the EZ-Cytox 3000 kit as described previously. Results from the cell viability experiments are expressed as the percentage of cell viability compared to that of the non-treated control.

\subsection{Statistical Analysis}

Statistical analysis was performed using SPSS 18.0 (SPSS Inc.). Averages and standard deviations were calculated and differences between groups were assessed using the analysis of variance method and Duncan's multiple range test. Differential values were considered significant if $p<0.05$.

\section{Results and Discussion}

\subsection{Properties of $I A 3 D$}

The infill density parameter ranges from $0 \%$ to $100 \%$, where $0 \%$ of infill results in a completely hollow object and that of 100\% results in a completely solid object [9]. By modifying the infill density parameter (10-50\%), different 3D scaffolds were fabricated using IA3D (Figure 2A). The approximate height of 3D scaffolds was $209 \pm 12 \mu \mathrm{m}$. The shapes of the resultant pores were rectangular and the average pore dimensions, which was also named the pore size (XY), were inversely correlated to the infill density. Indeed, pore size decreased from approximately $1890 \mu \mathrm{m} \times 1907 \mu \mathrm{m}(10 \%$ of infill 
density), $740 \mu \mathrm{m} \times 752 \mu \mathrm{m}$ ( $20 \%$ of infill density), $377 \mu \mathrm{m} \times 380 \mu \mathrm{m}$ (30\% of infill density), $248 \mu \mathrm{m} \times$ $250 \mu \mathrm{m}$ ( $40 \%$ of infill density) to $161 \mu \mathrm{m} \times 168 \mu \mathrm{m}$ (50\% of infill density) ( $n \geq 5)$, (Figure 2A). Further measurements of porosities showed a linear decrease from $83.3 \%, 73.1 \%, 53.8 \%$, and $29.8 \%$ to $22.6 \%$ for the 3D scaffolds with infill densities of $10 \%, 20 \%, 30 \%, 40 \%$, and 50\%, respectively $(p<0.05)$ (Figure 2B). However, the dry weight of scaffolds linearly increased from $2.22 \mathrm{mg}, 3.60 \mathrm{mg}, 6.10 \mathrm{mg}$, and $8.97 \mathrm{mg}$, to $9.73 \mathrm{mg}$ for the scaffolds with infill density of $10 \%, 20 \%, 30 \%, 40 \%$, and $50 \%$, respectively $(p<0.05)$ (Figure 2C). Studies have demonstrated that the porosity and pore size are some of the most significant characteristics of 3D printed scaffolds in tissue engineering [26-32]. In fact, scaffolds with adequate pore size and porosity provide a suitable microenvironment for sufficient cell-cell interaction and cell migration, proliferation, and differentiation [29]. It is also important to note that excessively small pores in scaffolds prevent cells from migrating in toward the center of the construct, consequently limiting the diffusion of nutrients and the removal of waste products. On the other hand, in larger pores (i.e., $325 \mu \mathrm{m}$ as the mean pore size used for skin cell culture [27]), cell aggregations are reduced, and cell attachment is limited as a result of the decreased available specific area [28]. Moreover, Gregor et al. demonstrated that for bone tissue replacement, a porosity of $30 \%$ (and not $50 \%$ ) is optimal for PLA scaffolds printed by the fused deposition modeling technique [33]. Indeed, the cultured osteosarcoma cell line MG-63 exhibited more successful proliferation and osteoconduction with only $30 \%$ porosity in comparison to the $50 \%$ porosity scaffold groups. Yang et al. investigated the optimal pore size $(200,350$, or $500 \mu \mathrm{m}$ ) of bone tissue implants and found that the $350 \mu \mathrm{m}$ scaffolds exhibited a better expression level of osteogenic genes [34]. In addition, the optimal pore size for ligament tissue ingrowth in braided ligament scaffolds in PLAGA 10:90 braids was found to be between 175 and $233 \mu \mathrm{m}$ [35]. Therefore, to select the 3D scaffold with adequate porosity and pore size for the cell ingrowth preferentially in a spheroid shape, cell culture experiments were performed.

(A)

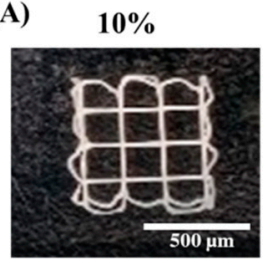

$20 \%$

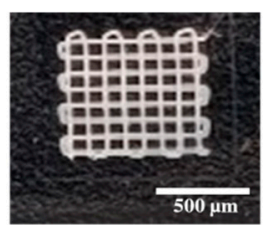

$30 \%$

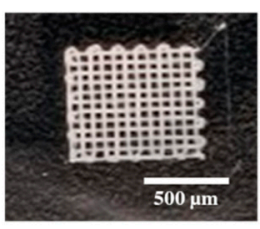

$40 \%$

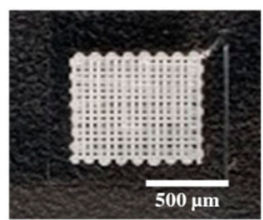

$50 \%$

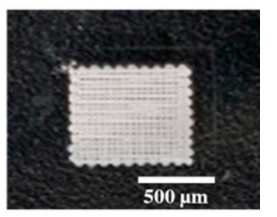

(B)

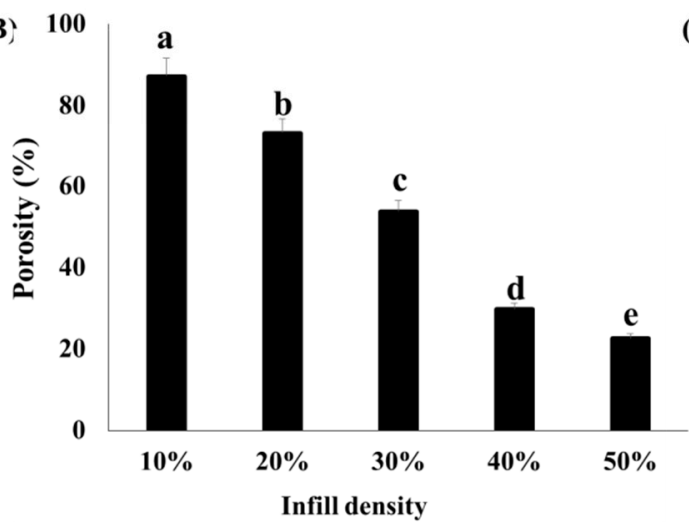

(c)

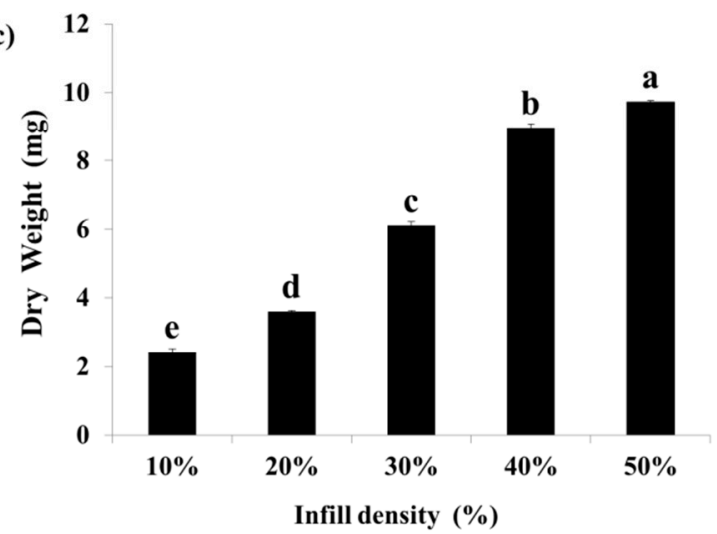

Figure 2. Characteristics of three-dimensional printed industrial acrylonitrile butadiene styrene scaffolds with different infill densities (10\%-50\%). (A) Photographs of industrial ABS scaffolds with infill densities ranging from $10 \%$ to $50 \%$. Scale bar: $500 \mu \mathrm{m}$. (B) Measured porosity. (C) Measured dry weight. Results are expressed as mean \pm SD. Significant differences $(p<0.05)$ are represented using different letters. 


\subsection{Optimization of the Infill Density and Cell Seeding Density in IA3D}

Live/Dead staining was performed to determine the scaffold with optimal infill density by seeding the human keratinocytes HaCaT cells at $5 \times 10^{4}$ cells/mL in IA3D $(10 \%, 20 \%, 30 \%, 40 \%$, and $50 \%$ of infill density) (Figure 3). At day 1 of incubation, scaffolds printed with 10\% and $20 \%$ infill densities exhibited higher toxicity to cells than the scaffolds with 30\%, 40\%, and 50\% infill densities (Figure 3). At day 4 of incubation, dead cells were found in 2D culture systems, whereas HaCaT cells cultured in scaffolds with $30 \%, 40 \%$, and $50 \%$ infill densities did not show dead cells. At day 5 of incubation, dead cells appeared in the scaffolds with $30 \%$ and $40 \%$ infill densities. Similar to the 2D culture, in scaffolds with $10 \%$ and $20 \%$ infill densities, cells were spreading on the internal flat surface of the pores, reducing the strength of cell-cell interactions. However, in scaffolds with $40 \%$ and $50 \%$ infill densities, tight structures of cells aggregates appeared from day 1 of culture, while the cell aggregates were formed later in the scaffolds with $30 \%$ infill density at day 7 of incubation. Overall, we found that the propensity to form 3D cell aggregates was highly correlated to the infill density. In this study, an IA3D with higher infill density (lower porosity) promoted cells' aggregation, while the scaffolds with lower infill density (higher porosity) promoted cell spreading. These findings are in accordance with recent studies in which higher porosities were shown to promote cell spreading on the internal surface of bigger pores, whereas the lower porosities promoted 3D cell aggregation [30]. 3D scaffolds with an infill density of $50 \%$ performed better than those with an infill density of $40 \%$ in promoting cell aggregation, but it was difficult to observe the cells under microscope in IA3D with $50 \%$ infill because of the narrow pore size and high fluorescent signal density from stained cells. Recent studies in tissue engineering recommended scaffolds with pore sizes ranging from 200 to $300 \mu \mathrm{m}$ for the growth of tissues such as fibrocartilaginous tissue [36]. It has been established that cell proliferation on scaffolds is highly correlated with the material, scaffold structure, and cell kinetics [37]. This study is the first report showing that scaffolds fabricated using industrial ABS filament are effective in promoting the viability and proliferation of cells. Therefore, we decided to conduct our experiments by using the IA3D fabricated with $40 \%$ infill density (porosity $29.8 \%$, pore size: approximately $248 \mu \mathrm{m} \times 250 \mu \mathrm{m}$ ) (Figure 2). 


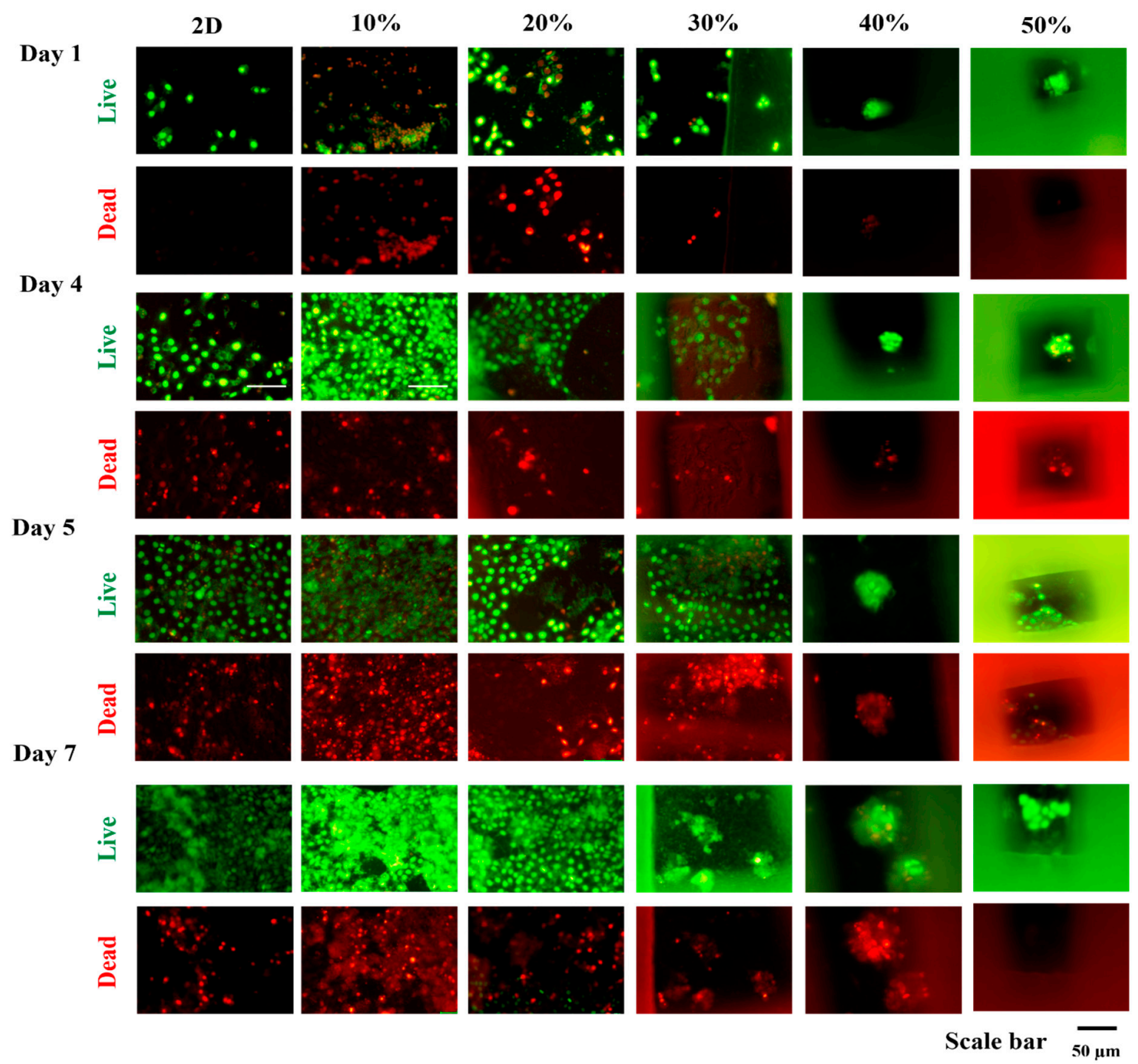

Figure 3. Live/Dead staining of keratinocytes human keratinocyte cells (HaCaT) cells cultured in three-dimensional printed industrial acrylonitrile butadiene styrene scaffold printed with different infill densities ranging from $10 \%$ to $50 \%$. Cells were seeded at $5 \times 10^{4}$ cell $/ \mathrm{mL}$; scale bar: $50 \mu \mathrm{m}$.

\subsection{Physical Properties of Au-NPs}

To improve the biocompatible properties of the industrial ABS material, Au-NPs were synthesized at high temperature $\left(60-90^{\circ} \mathrm{C}\right)$ and coated on scaffolds (Figure 1). During synthesis, the color of the solution (gold [III] chloride and trisodium citrate) changed from colorless to purple and finally to ruby-red. These colors were thought to characterize the formation of gold nanoparticles in solution [38]. Further optical tests such as UV-vis and TEM assessments were performed to confirm these findings.

Figure $4 \mathrm{~A}$ shows the UV-vis wavelength spectra of Au-NPs colloidal solutions recorded from 380 to $780 \mathrm{~nm}$. The evolution of UV-vis peaks in Au-NPs synthesized at $60{ }^{\circ} \mathrm{C}, 70{ }^{\circ} \mathrm{C}, 80{ }^{\circ} \mathrm{C}$, and $90{ }^{\circ} \mathrm{C}$ showed a decrease in the wavelength number associated with the increase in temperature. Indeed, the corresponding peaks of Au-NPs peaks synthesized at $60^{\circ} \mathrm{C}, 70{ }^{\circ} \mathrm{C}, 80^{\circ} \mathrm{C}$, and $90{ }^{\circ} \mathrm{C}$ were recorded as $529,522,521$, and $519 \mathrm{~nm}$, respectively. A similar conclusion was reached by Minh Tran et al. when synthesizing Au-NPs by the Turkevich approach [23-25]. They showed that temperature strongly influences the physical parameters of Au-NPs, including their corresponding UV-vis peaks and particle sizes [39]. In addition, according to the published literature, a lower wavelength value for the Au-NPs UV-vis peak is highly correlated with particles of a smaller diameter [40]. 
(A)
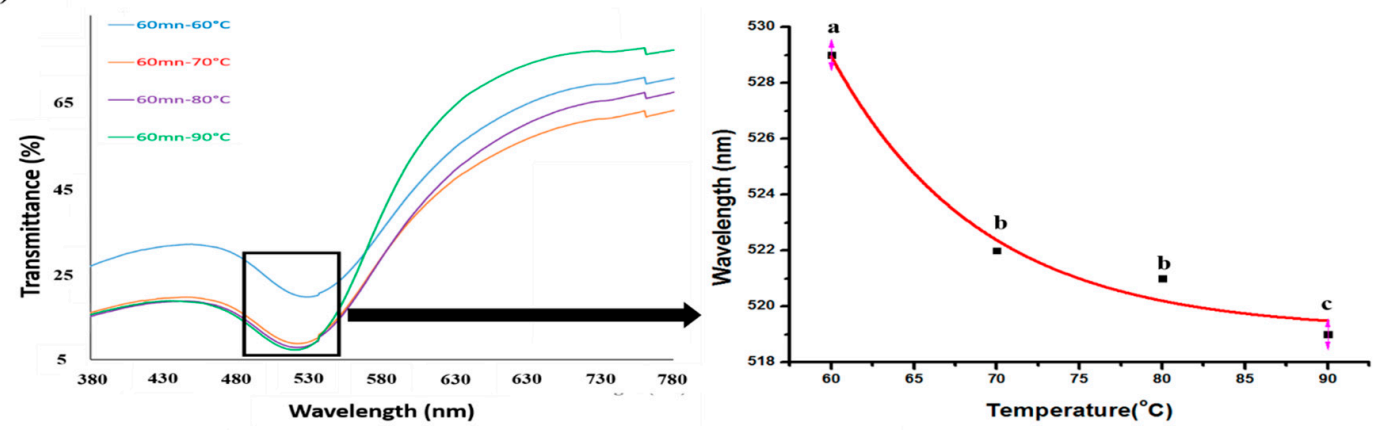

(B)

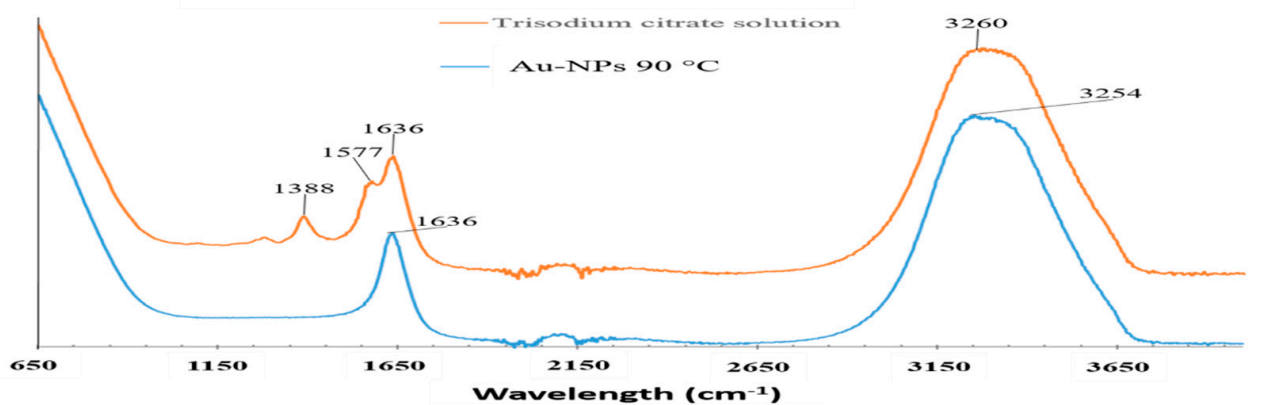

(C)
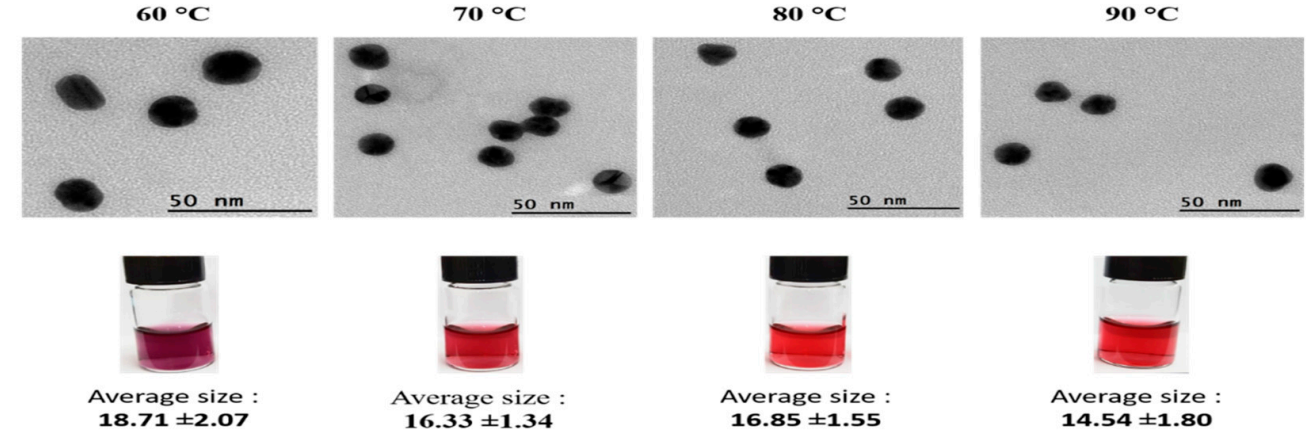

Figure 4. Optical characterization of gold nanoparticles (Au-NPs). (A) UV-vis transmittance spectra of Au-NPs colloidal solutions synthesized at high temperatures $\left(60\right.$ to $\left.90{ }^{\circ} \mathrm{C}\right)$ for $60 \mathrm{~min}$. Results are expressed as mean $\pm \mathrm{SD}, \mathrm{n}=3$. Significant differences $(p<0.05)$ are represented using different letters $(a, b, c)$. (B) The Fourier-transform infrared spectroscopy (FTIR) spectra of trisodium citrate solution $(88 \mathrm{~g} / \mathrm{L})$ and Au-NPs colloidal solution synthesized at $90^{\circ} \mathrm{C}$ for $60 \mathrm{~min}$. (C) TEM micrographs of gold nanoparticles synthesized at $60^{\circ} \mathrm{C}, 70^{\circ} \mathrm{C}, 80^{\circ} \mathrm{C}$, and $90^{\circ} \mathrm{C}$ corresponding to the respective photography of Au-NPs colloidal solutions. The mean sizes of all four samples were determined by counting at least 100 particles.

The FTIR spectra of trisodium citrate solution $(88 \mathrm{~g} / \mathrm{L})$ and Au-NP suspension synthesized at $90{ }^{\circ} \mathrm{C}$ are presented in Figure 4B. The characteristic peaks of trisodium citrate solution at $1388 \mathrm{~cm}^{-1}$ and $1577 \mathrm{~cm}^{-1}$ correspond to the symmetric and anti-symmetric stretching of carboxylate $\left(\mathrm{COO}^{-}\right)$. The peaks at $1636 \mathrm{~cm}^{-1}$ and $3254 \mathrm{~cm}^{-1}$ can be assigned to the $\mathrm{O}-\mathrm{H}$ scissor bonds and $\mathrm{O}-\mathrm{H}$ stretching bonds, respectively. These data confirm that citrate served as a capping agent in Au-NPs [41].

To further confirm the UV-vis results, TEM measurements were performed on Au-NPs samples synthesized from 60 to $90^{\circ} \mathrm{C}$ (Figure 4C). TEM micrographs revealed the synthesis of spherical particles. The decrease in nanoparticle size was also inversely correlated with the temperature of the reaction. Average particle sizes were $18.71 \pm 2.07 \mu \mathrm{m}, 16.33 \pm 1.34 \mu \mathrm{m}, 16.85 \pm 1.55 \mu \mathrm{m}$, and $14.54 \pm 1.80 \mu \mathrm{m}$ for nanoparticles synthesized at $60{ }^{\circ} \mathrm{C}, 70{ }^{\circ} \mathrm{C}, 80^{\circ} \mathrm{C}$, and $90{ }^{\circ} \mathrm{C}$, respectively (Figure $4 \mathrm{C}$ ). These findings indicate that Au-NPs could be effectively synthesized via the method modified from Turkevich and Frens (1951), (1973). 


\subsection{Characterization of Surface Modified GIA3D}

Figure $5 \mathrm{~A}, \mathrm{~B}$ show the SEM micrographs of the optimal scaffold ( $40 \%$ infill density model). The overall size of the printed scaffold was $7650 \pm 37.2 \mu \mathrm{m} \times 7647 \pm 41.9 \mu \mathrm{m} \times 210 \pm 9 \mu \mathrm{m}$, which is very close to the theoretical size of the pattern (XYZ), $8000 \mu \mathrm{m} \times 8000 \mu \mathrm{m} \times 210 \mu \mathrm{m}$. The scaffold fabricated with $40 \%$ infill density parameter presented 225 homogenous microenvironments (void spaces or pores) with an actual size $(X Y Z)$ of $251.6 \pm 11.2 \mu \mathrm{m} \times 245.9 \pm 16.9 \mu \mathrm{m} \times 210 \pm 9 \mu \mathrm{m}$, compared to the theoretical size of $250 \mu \mathrm{m} \times 240 \mu \mathrm{m} \times 210 \mu \mathrm{m}$. The overall porosity represented approximately $29.7 \%$ of the scaffold dimension (Figure 5A,B). In addition, the fibers presented a uniform size with a $279.15 \pm 19.4 \mu \mathrm{m}$ layer width. Thus, our findings indicate that the FDM technique reproduced the 3D scaffold pattern with high precision. FDM is one of the most commonly used rapid prototyping techniques in 3D printing; it is used widely in the automotive and aerospace industries, as it is capable of producing models for visualization and design verification, and it is also used in biomedicine, particularly for the fabrication of 3D scaffolds $[9,42]$. This reliable technology also enables the fabrication of porous scaffolds with complex geometry and controllable porosity [30]. The FDM technique is cost-effective and can be customized to yield scaffolds suitable for specific tissues and organs [43]. In addition, the FDM technique does not require any solvent to reproduce layer-by-layer 3D scaffold designs via computer models from polymeric thermoplastic, ceramic, and metallic materials [44].

(A)

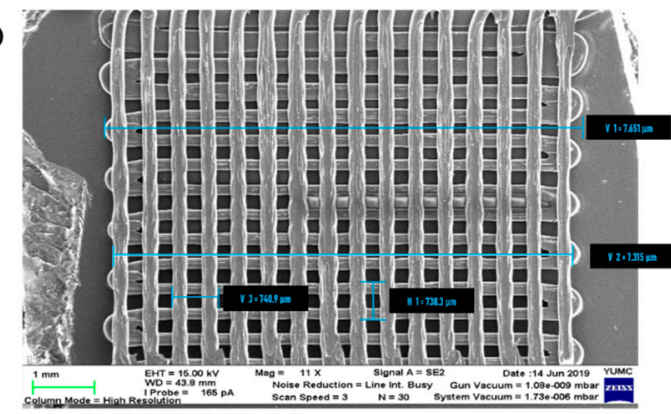

(B)

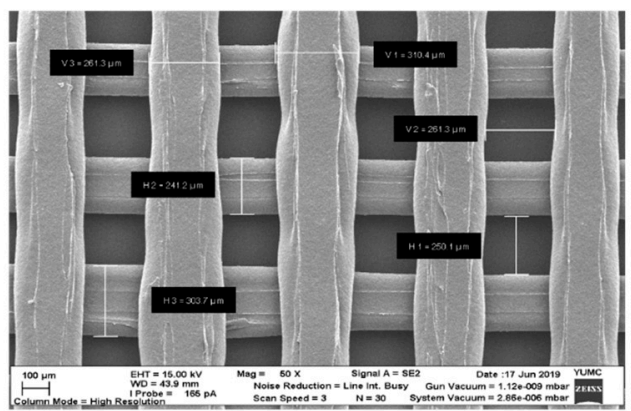

(C)

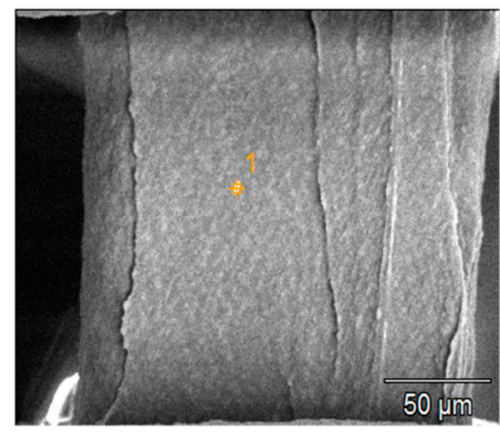

Full scale counts: 2084

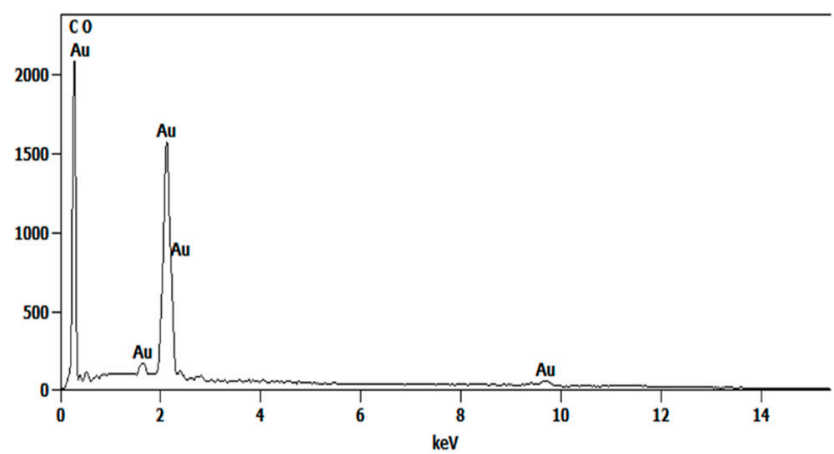

Figure 5. Optical characterization of the gold nanoparticles (Au-NPs)-coated industrial acrylonitrile butadiene styrene scaffold (GIA3D), printed with an infill density of $40 \%$. (A) SEM images of the three-dimensional printed industrial acrylonitrile butadiene styrene scaffolds (IA3D) with $40 \%$ infill density showing the overall size. Scale bar $1 \mathrm{~mm}$. (B) SEM images of the IA3D with $40 \%$ infill density showing pore size and fiber width. Scale bar: $100 \mu \mathrm{m}$. (C) Authentication of GIA3D with SEM, scale bar $50 \mu \mathrm{m}$. SEM, scanning electron microscopy; EDS, energy-dispersive X-ray spectroscopy.

EDS data was analyzed to examine the elemental composition of the particles found on the surface of IA3D fibers and their surroundings (Figure 5C). The results clearly confirmed the presence of metallic Au. In this study, we treated GIA3D (14.54 nm, Figure 4C) synthesized from a $\mathrm{HAuCl}_{4}$ solution containing $0.25 \mathrm{mM}$ of $\mathrm{Au}^{3+}$ ions. It is important to highlight the fact that $\mathrm{Au}-\mathrm{NPs}$ can be 
incorporated into scaffold structures to upgrade the biocompatibility of the resultant nanocomposite. This was confirmed recently by proving that Au-NPs-incorporated macroporous scaffolds increased the matrix conductivity of the scaffold and promoted cell adhesion, growth, differentiation, maturation, and morphogenesis [15-17].

\subsection{Morphology of Cells in G2D and GIA3D}

SEM imaging of Figure 6 showed the difference in the morphology of cells grown on GIA3D and G2D. In 2D-plated culture, Au-NPs coating is an efficient technique to reinforce cell adhesion and growth or bind functional compounds for enhancing extracellular matrix properties [45]. The SEM image of HepG2 cells and HaCaT cells cultured on G2D appeared to show a flat and well-spread morphology with microvilli on the surface. In addition, our results showed the similar pattern between G2D and 2D (Figures 6 and 7A). However, a morphologic image of HepG2 and HaCaT cells cultured on GIA3D showed spheroidal structures after $48 \mathrm{~h}$ incubation. In addition, GIA3D revealed a significantly greater number of spheroids than that observed for cells grown on G2D. Therefore, our structures allowed for a faster and easier method for culturing HepG2 and HaCaT cells in a spheroid manner.
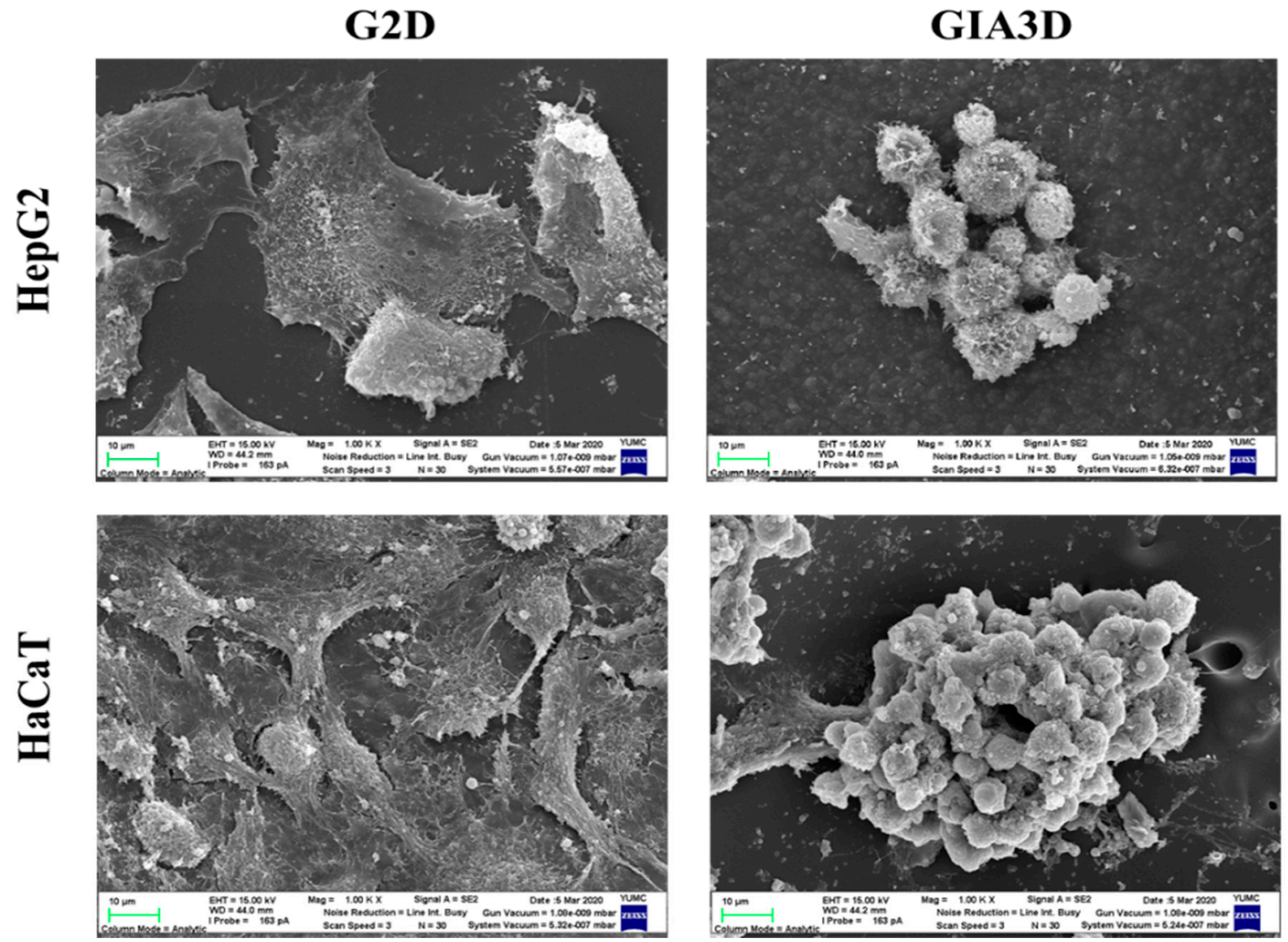

Figure 6. Morphology of human hepatoma cells (HepG2) and HaCaT cells in gold nanoparticles-coated 2D plate (G2D) and Au-NPs-coated industrial ABS scaffold (GIA3D) using SEM. Scale bar: $10 \mu \mathrm{m}$. 
(A)
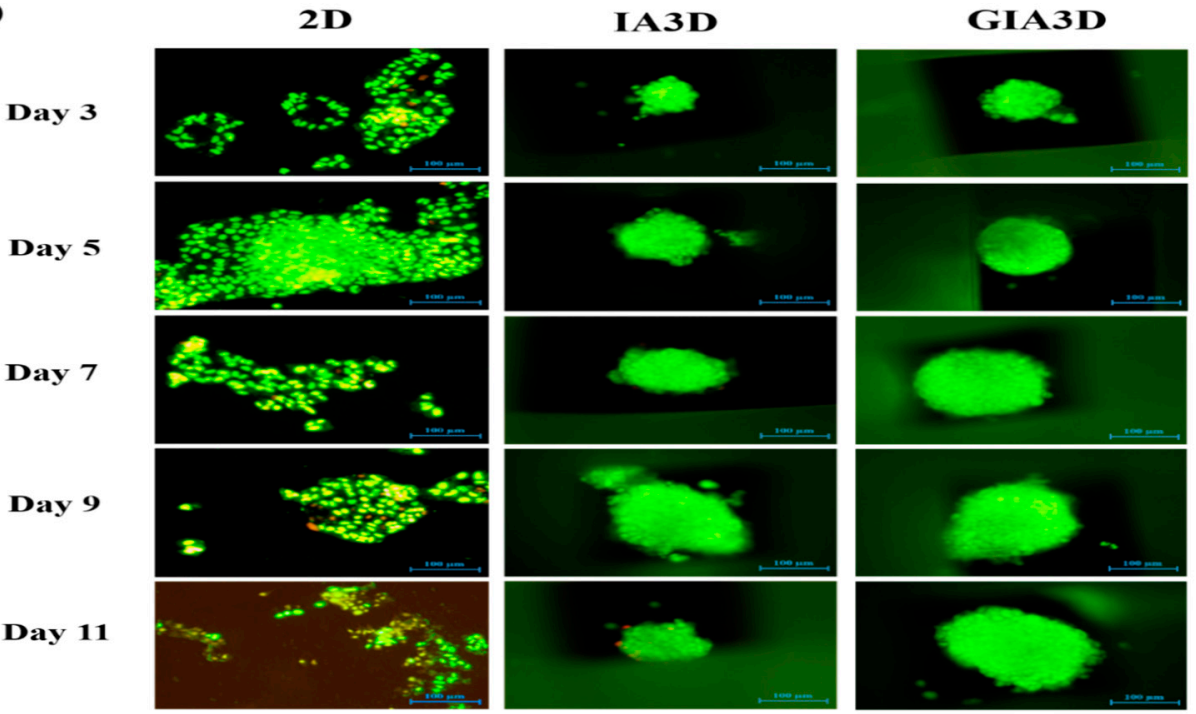

(B)
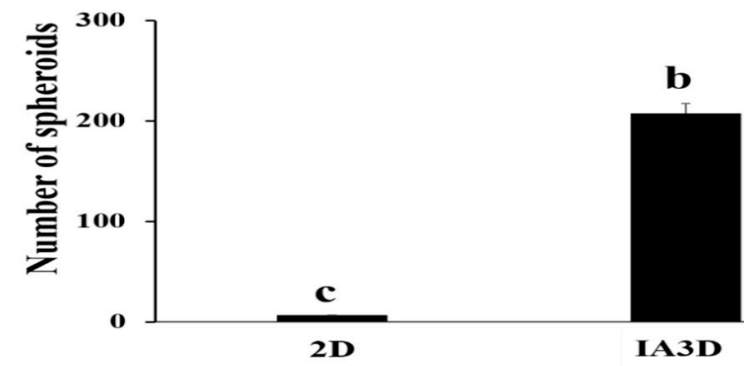

a

(C)
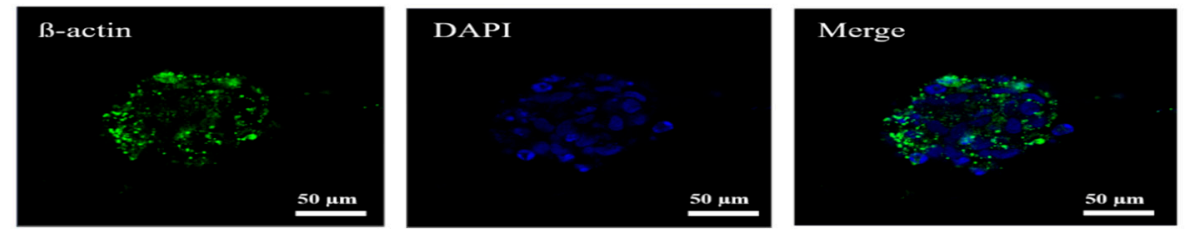

Figure 7. Evaluation of cell proliferation and spheroid stimulation in gold nanoparticle (Au-NPs)-coated industrial acrylonitrile butadiene styrene (ABS) scaffold. (A) Live/dead staining micrograph of HepG2 cells cultured for 11 days in two-dimensional culture, industrial ABS scaffold (IA3D), and Au-NPs-coated industrial ABS scaffold (GIA3D); live cells are stained in green. Scale bar, $100 \mu \mathrm{m}$. (B) Number of HepG2 spheroids formed after a three-day culture in IA3D and GIA3D. Results are expressed as mean \pm SD. Significant differences $(p<0.05)$ are represented using different letters $(a, b, c)$. (C) Confocal microscopy images of HaCaT cells stained with F-actin (green) using a FITC-conjugated antibody (left micrograph). Nuclei (blue) stained with 4', $6^{\prime}$-diamidino-2-phenylindole (DAPI) (middle micrograph). Merged image of F-actin and DAPI staining (right micrograph). The images were obtained using a Carl Zeiss LSM 800 confocal laser scanning microscope, LSM imaging software (Carl Zeiss). Scale bar $50 \mu \mathrm{m}$.

\subsection{Enhancement of Long-Term Cell Culture in Surface-Modified GIA3D}

To evaluate whether the GIA3D improved the proliferation of cell spheroids, we performed live/dead staining and immunostaining assays (Figure 7). As shown in Figure 7A, the proliferation of tumor HepG2 cells was compared via a long-term culture system (2D versus 3D). Results showed that in the 2D system, the number of living cells markedly increase from 3 days to 5 days of culture but deplete thereafter until 11 days of culture. However, in the 3D culture approach, the number of living cells decreased in the IA3D from 9 days on, and almost all of the cells cultured in GIA3D were viable at 11 days. The substantial increase in cell proliferation that occurred in the 2D culture model raised the number of live cells, resulting in approximately $95 \%$ confluence at 5 days, which likely triggered overcrowding-induced cell death. 
In addition, in Figure 7B, the number of HepG2 spheroids obtained after $72 \mathrm{~h}$ of culture was higher in GIA3D in comparison to IA3D (1.3-fold) and 2D models (38-fold) $p<0.05$.

To further investigate the cell morphology of normal cell (keratinocytes, HaCaT cells) cultured in GIA3D, we analyzed confocal z-stack sections of individual colonies. After 3 days of culture, HaCaT cells stained with F-actin and blue fluorescence (i.e., DAPI, or 4' $6^{\prime}$-diamidino-2-phenylindole staining) was observed in the nuclei of cells (Figure 7C). Three-dimensional (3D) cell aggregates were found between the pores of the scaffold (Figure 7C). The spheroidal structure of $\mathrm{HaCaT}$ cells appeared rapidly in GIA3D after 3 days of incubation.

In recent reports, the incorporation of Au-NPs in scaffold structure promotes cell growth and viability [15]. Au-NPs are known to positively influence the proliferation, maturation, and differentiation of cells in 3D scaffold culture. For instance, the growth and proliferation of neurons and cardiac cells were boosted when cells were cultivated on Au-NPs-decorated electrospun nanofiber scaffolds and within coiled fiber scaffolds embedded with gold nanoparticles, respectively [16,18,19]. Additionally, the Au-NPs-induced activation of cell adhesion, growth, and proliferation is strongly correlated with the particles' shape and size. Zeng et al. showed that the spherical nano-size of Au-NPs (15-nm), ranging from 0 to $200 \mathrm{pM}$, did not negatively influence HepG2 cell growth even at their highest tested dose, whereas a larger particle size $(30 \mathrm{~nm})$ decreased the viability of cells [46]. Furthermore, Huang et al. proved that $15 \mathrm{~nm}$ Au-NPs are not able to penetrate deeply into tumor spheroids [47]. Herein, we have coated the surface of IA3D with a similar spherical particle size (14.54 nm) of Au-NPs (Figure 4C). Interestingly, instead of inducing a cytotoxic effect or decreasing the proliferation of tumor HepG2 cells, Au-NPs promoted cell growth and proliferation. Additionally, other studies have also demonstrated an increase in the number of spheroids found in cells cultured with Au-NPs, including Pavlovich et al. 2016, which reported that small concentrations of nanoparticles $(1-3 \mu \mathrm{g} / \mathrm{mL})$ with $15 \mathrm{~nm}$ diameters stimulated multicellular spheroid formation by HT29 (colorectal carcinoma cell line) and SPEV Cells (embryonic porcine kidney epithelial inoculated cell line) [48].

Our findings suggest that the chosen size of Au-NPs, as well as the coating methods, are effective in promoting the proliferation of the cancer model HepG2 cells, in addition to accelerating the formation and growth of $\mathrm{HaCaT}$ spheroids. A similar pattern of results was obtained by Chandrasekaran et al. by culturing the $\mathrm{HaCaT}$ cells in microbubbles under standard conditions. They observed a compact 3D spheroidal morphology of $\mathrm{HaCaT}$ cells within 2-3 days [49]. Our findings may suggest that Au-NPs are useful tools for improving the biocompatibility of industrial materials such as IA3D and serve to broaden the application of this kind of material in the biomedical field. Herein, we report that our newly engineered GIA3D facilitate cell proliferation and the formation of 3D cell spheroids.

\subsection{Improvement of Cell Viability in Surface-Modified GIA3D}

To confirm the improved biocompatibility of GIA3D, we assessed the viability of cancer HepG2 cells and normal HaCaT cells by culturing the cells in a 2D system, IA3D, and GIA3D for 6, 24, 48, and $72 \mathrm{~h}$ (Figure 8). For HepG2 cells, the three cell culture types exhibited different patterns of cell growth according to the cell seeding density and incubation time (Figure 8A). Cell viability curves showed a slight increase in the quantity of cells from $0 \mathrm{~h}(100 \%)$ to $6 \mathrm{~h}$ only for cells seeded at $3 \times 10^{3} \mathrm{cell} / \mathrm{mL}$ in GIA3D (113\%) and 2D culture (110\%). By contrast, for cells seeded at $1 \times 10^{3}$ cell $/ \mathrm{mL}$ and $2 \times 10^{3} \mathrm{cell} / \mathrm{mL}$, cell viability decreased regardless of cell culture type at $6 \mathrm{~h}$ of culture. Afterwards, from 6 to $48 \mathrm{~h}$, cell viability notably increased in all cell culture types according to cell density. For cells seeded at a density of $3 \times 10^{3}$ cell $/ \mathrm{mL}$, cell viabilities were $219 \%$ in GIA3D versus $241 \%$ in $2 \mathrm{D}$ and $186 \%$ in IA3D at $48 \mathrm{~h}$. Intriguingly, at $72 \mathrm{~h}$, the viabilities of HepG2 cells significantly declined for seeding densities of $2 \times 10^{3} \mathrm{cell} / \mathrm{mL}$ and $3 \times 10^{3} \mathrm{cell} / \mathrm{mL}$ regardless of the cell culture type, except in the GIA3D culture at $3 \times 10^{3} \mathrm{cell} / \mathrm{mL}$ and $1 \times 10^{3} \mathrm{cell} / \mathrm{mL}$. 
(A)

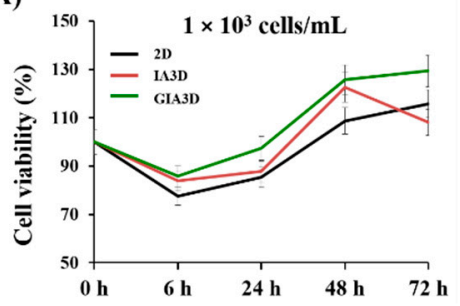

(B)
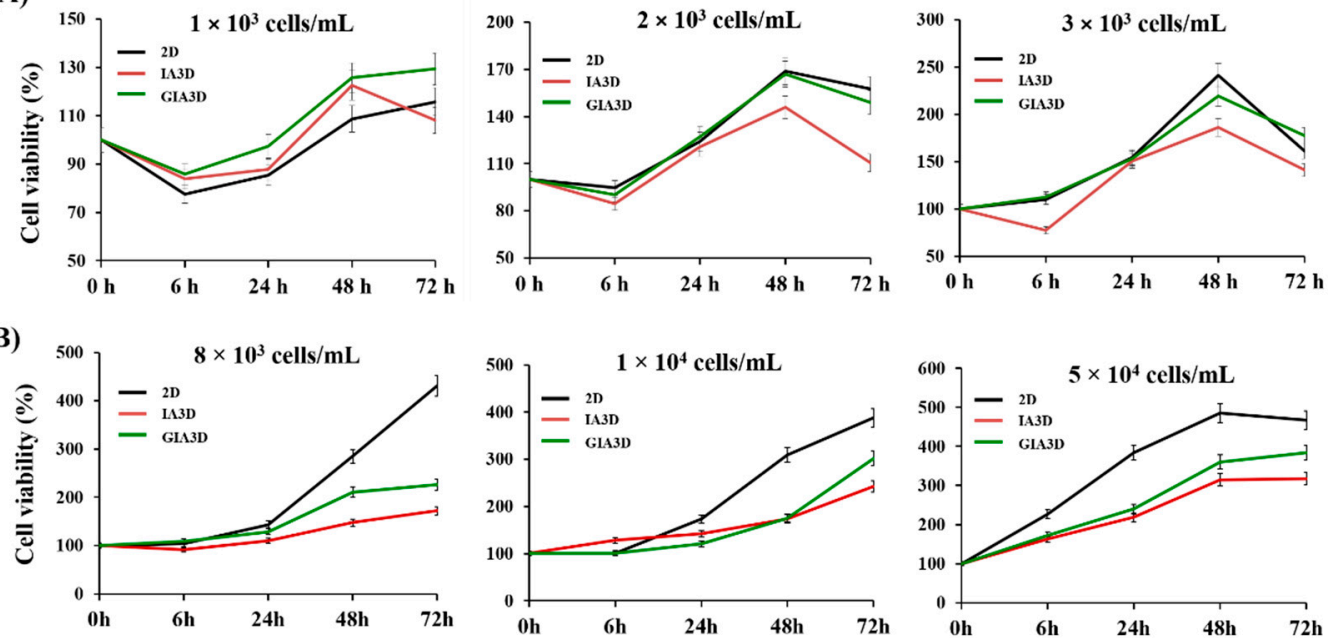

(C)
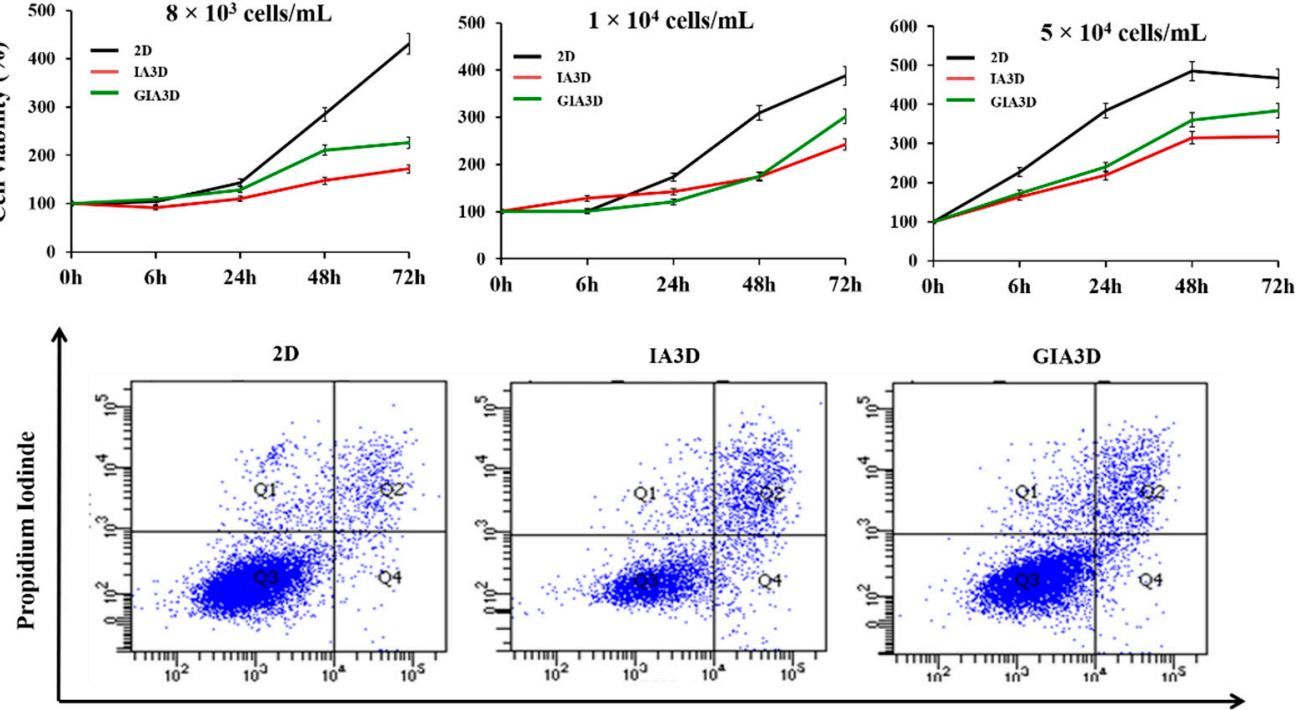

Annexin V-FITC
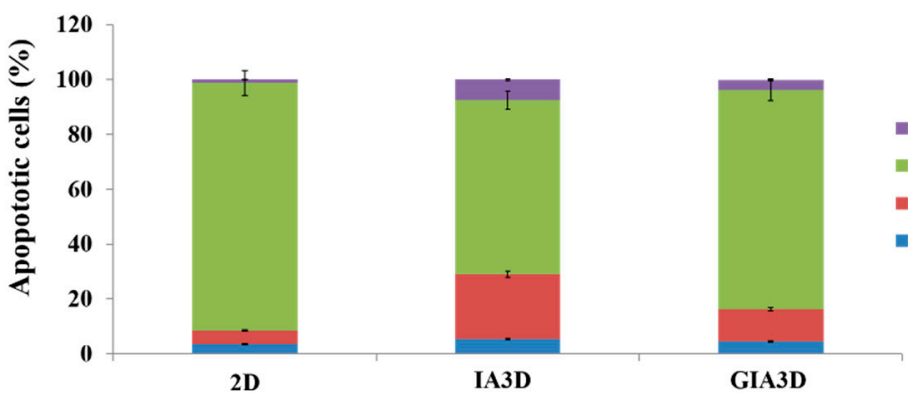

- Early apoptotic cells

- Viable cells

- Late apoptotic cells

- Necrosis

Figure 8. Evaluation of HepG2 and HaCaT cells viabilities. (A,B) Viabilities of HepG2 cells, $\mathrm{HaCaT}$ cells in two-dimensional culture, industrial acrylonitrile butadiene styrene (IA3D), and gold nanoparticle-coated ABS scaffold (GIA3D). Cells were seeded at a density ranging from $1 \times 10^{3}-3 \times 10^{3}$ cell $/ \mathrm{mL}$ for HepG2 cells to $8 \times 10^{3}-5 \times 10^{4}$ cell $/ \mathrm{mL}$. Viabilities were measured at $0 \mathrm{~h}, 6 \mathrm{~h}, 24 \mathrm{~h}, 48 \mathrm{~h}$, and $72 \mathrm{~h}$ of culture. The percentage (\%) of viable cells was calculated and plotted. Results are expressed as mean $\pm S D, n=3$. (C) Determination of the apoptotic HaCaT cell populations by Annexin V-FITC/propidium iodide staining in 2D culture, IA3D, and GIA3D. Cells were cultured at a density of $5 \times 10^{4}$ cells/mL for 3 days. The experiments were performed in triplicate. After 3 days of culture, IA3D induced cell apoptosis (31.2\%), which was lower in the GIA3D scaffold (15.3\%) and minimal in 2D culture (9.2\%).

The growth of HaCaT cells in the three cell culture types increased according to the cell density and incubation time (Figure $8 \mathrm{~B}$ ). There was a slight increase in cell viability between 0 and $24 \mathrm{~h}$ of culture for cells seeded at $8 \times 10^{3}$ cell $/ \mathrm{mL}$ and $1 \times 10^{4}$ cell $/ \mathrm{mL}$ regardless of cell culture type, whereas for densities of $5 \times 10^{4}$ cell $/ \mathrm{mL}$, cell viabilities notably increased only after $6 \mathrm{~h}$ of culture (172\% in GIA3D versus $226 \%$ in $2 \mathrm{D}$ and $162 \%$ in IA3D). Moreover, from 24 to $72 \mathrm{~h}$ of culture, the viability of HaCaT cells was higher in 2D culture regardless of cell density, followed by the GIA3D culture. For cells seeded at $5 \times 10^{4}$ cell/mL, cell viabilities after $72 \mathrm{~h}$ of culture were $384 \%$ in GIA3D versus $431 \%$ in $2 \mathrm{D}$ and $317 \%$ 
in IA3D cultures. Thus, we used cell densities of $3 \times 10^{3} \mathrm{cell} / \mathrm{mL}$ and $5 \times 10^{4}$ cell $/ \mathrm{mL}$ for cancer HepG2 cells and normal $\mathrm{HaCaT}$ cells in drug screening experiments, respectively.

Apoptotic cells were quantified by Annexin V-FITC staining in HaCaT cells. As shown in Figure 8C, $31.2 \%$ of apoptotic cells were observed in the IA3D as opposed to the GIA3D (15.3\%) and 2D culture groups $(9.2 \%)$. These results also confirmed that Au-NPs increase the biocompatibility of the IA3D, improving the rate of cell proliferation and protecting $\mathrm{HaCaT}$ cells from apoptosis. Our knowledge of the apoptotic process is limited without assays to better understand the mechanism of apoptotic induction. Breslin et al. found that apoptotic markers including caspase 3, caspase 7, and caspase 9 are increased in 3D cells compared to 2D cells [50]. Similarly, our findings demonstrated an increase of apoptotic cells in 3D cultured when compared with the 2D culture.

Together, the present findings confirm that the cytotoxicity induced in the IA3D was reduced with Au-NPs coating; thus, Au-NPs improved the biocompatibility of IA3D. Additionally, we found that the GIA3D was more efficient than the 2D culture system in maintaining the viability of HepG2 cancer cells, while in normal HaCaT cell cultures, higher viability was observed in 2D culture as opposed to GIA3D. These findings support the notion that the type of material and cell-type are critical to preventing adverse effects in 3D cell culture [37]. In 2D culture, cells grow continuously when there is enough space, but the 3D culture systems do not follow the same growth pattern [51]. Due to the tight structure of cell spheroids in the 3D culture, the amount of oxygen and nutrients received by cells in the center of the structure is reduced in comparison to the outer cells, which can lead to the death and necrosis of cells in the core of structure. However, the outer cell layers of the spheroid undergo a higher proliferation rate [51]. This may explain why the cell viability in 3D cultures is likely to be reduced compared to $2 \mathrm{D}$ cultures. Rabionet et al. demonstrated that breast cancer cells cultured in $15 \%$ PCL and 7.5\% PCL scaffolds were less proliferative in comparison to cells cultured in a monolayer [52]. In addition, the proliferation of a range of colon cancer cell lines (Caco-2, DLD-1, HT- 29, SW-480, LoVo, COLO-205, and COLO-206f) grown in 3D using Matrigel was decreased compared to the growth observed in 2D cells [53].

\subsection{Cytotoxicity of Drugs in HepG2 and HaCaT Cells Cultured on GIA3D}

The 3D cell models have become useful tools for mimicking in vivo conditions, and they can be used for more effective drug screening applications [1]. To evaluate the sensitivity of both cancer and normal cells to drugs, we treated the cultured cancer HepG2 cells and normal skin HaCaT cells with mitoxantrone and asiatic acid (AA) in IA3D and GIA3D as well as 2D culture. In cancer cells, mitoxantrone treatment $(1-100 \mu \mathrm{M})$ resulted in a dose-dependent reduction in the viability of HepG2 cells cultured in 2D culture and IA3D in comparison with untreated cells (Figure 9A).

However, in the GIA3D, the percentage of viable cells remained higher than that observed in the untreated cells regardless of the drug dose (Figure 9A). In fact, mitoxantrone linearly decreased the viability of cells up to $55.2 \%$ in $2 \mathrm{D}$ culture and $40.2 \%$ in IA3D culture at a dose of $100 \mu \mathrm{M}$, while in the GIA3D, cell viability was increased $(p<0.05)$. The AA $(0-200 \mu \mathrm{M})$ screening test in HepG2 cells demonstrated that $10 \mu \mathrm{M}$ of the drug markedly increased the viability of cells only when cultured in GIA3D (118\%) in comparison with untreated cells. However, no significant difference was observed in all three cell culture types when cells were intoxicated with $10 \mu \mathrm{M}$ and $75 \mu \mathrm{M}$ of AA $(p<0.05)$ (Figure 9B). By contrast, a notable decrease in cell viability was noticed in cells treated with 150 and $200 \mu \mathrm{M}$ of AA in 2D culture (74.1\% and $68.1 \%$, respectively) and IA3D (79.5\% and $76.9 \%$, respectively) $(p<0.05)$. Interestingly, in cells cultured in the GIA3D, no significant changes were observed with the same concentrations of 150 and $200 \mu \mathrm{M}(p<0.05)$. Our findings show that cancer HepG2 cells and normal HaCaT cells were less sensitive to mitoxantrone and AA in GIA3D culture than in IA3D and 2D cultures. 
(A)

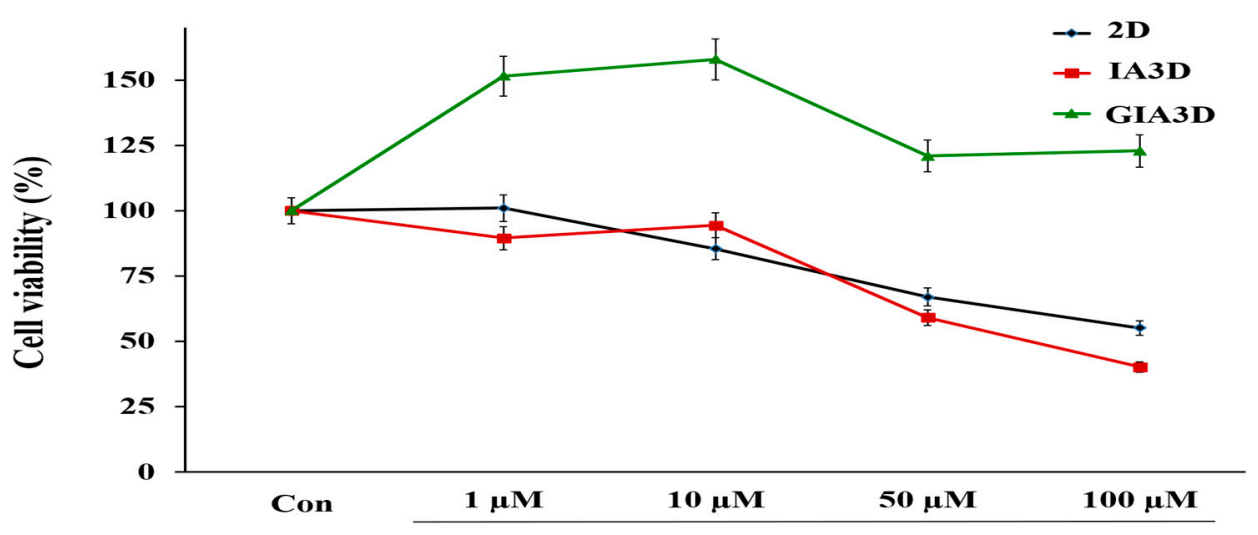

(B)

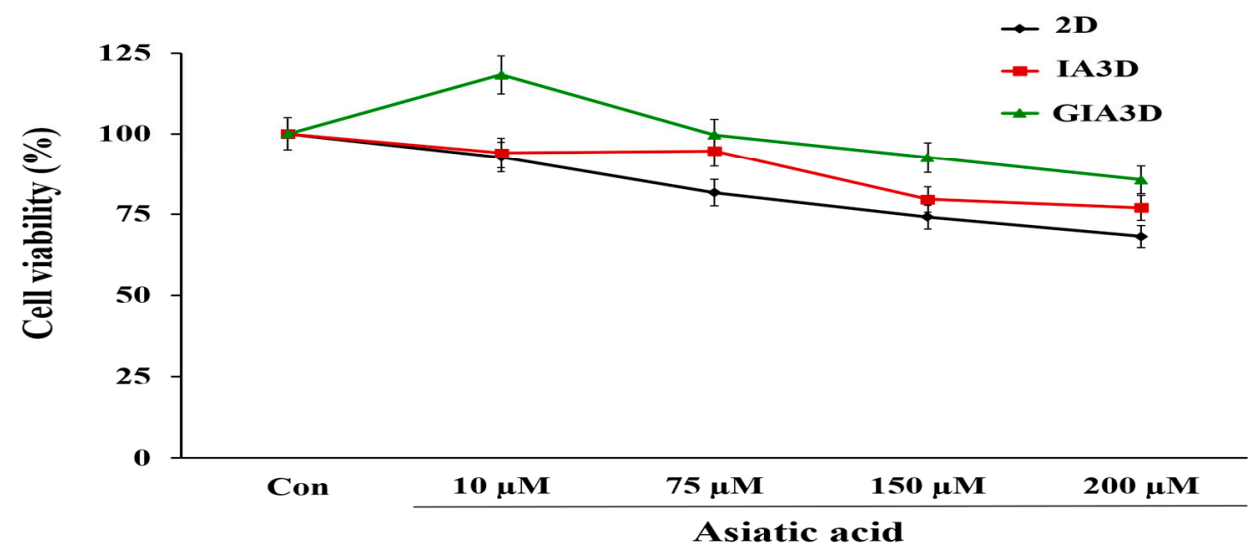

Figure 9. Cytotoxic effects of drugs on HepG2 cells. (A,B) Effects of mitoxantrone and asiatic acid drugs on HepG2 cells cultured in two-dimensional culture, industrial acrylonitrile butadiene styrene, and gold nanoparticle-coated ABS scaffold. The cells were seeded at $3 \times 10^{3}$ cell $/ \mathrm{mL}$, incubated for $72 \mathrm{~h}$ afterward, and treated with mitoxantrone $(1-100 \mu \mathrm{M})$ or asiatic acid $(10-200 \mu \mathrm{M})$ for $24 \mathrm{~h}$. The relative cell viabilities were calculated as the percentage of untreated cells. Results are expressed as mean $\pm \mathrm{SD}$, $\mathrm{n}=3$.

In addition, the sensitivity to mitoxantrone and $\mathrm{AA}$ was investigated in $\mathrm{HaCaT}$ cells cultured in IA3D, GIA3D, and 2D cultures (Figure 10A,B). The viability of HaCaT cells treated with $0.1 \mu \mathrm{M}$ mitoxantrone dropped significantly to $85.76 \%$ in GIA3D, $53.59 \%$ in $2 \mathrm{D}$, and $72.15 \%$ in IA3D culture when compared with corresponding untreated cells. However, with mitoxantrone doses of $0.3 \mu \mathrm{M}$ and $0.8 \mu \mathrm{M}$, cell viabilities were higher in IA3D culture, followed by GIA3D and 2D culture $(60.5 \%$ in IA3D versus approximately $29 \%$ in GIA3D and 2D for $0.8 \mu \mathrm{M}$ of AA). On the other hand, in AA intoxication, no significant changes were observed in the viabilities of HaCaT cells treated with 50 and $100 \mu \mathrm{M}$ in all cell culture types compared with untreated cells. However, 200 and $300 \mu \mathrm{M}$ of AA notably decreased cell viability in all cell culture types up to approximately $34-38 \%$.

Mitoxantrone is a quinone-based drug recognized as a FDA-approved compound for use as an anticancer agent [54]. For example, the drug was shown to exhibit cytotoxic activities in liver carcinomas [55]. For instance, in hepatocellular carcinoma HepG2 cells, mitoxantrone have been shown to induce cell death with autophagy involvement [55]. In the current study, mitoxantrone reduced the viability of HepG2 cells cultured in 2D and IA3D, whereas no toxicity was observed in cells cultured in GIA3D, even at the highest tested concentration $(100 \mu \mathrm{M})$. AA is a pentacyclic triterpene that is mainly found in Centella asiatica, which is proven to induce a significant anti-proliferative effect and death in cancer cells such as HepG2 [56,57]. Our findings show that the AA treatment resulted in a greater reduction in cell viability of HepG2 cells in 2D culture than that observed in both IA3D. Especially 
in the GIA3D, cells were less sensitive to AA compared with IA3D. Hickman et al. revealed that the tight structure of HepG2 cell aggregates in 3D scaffold structures limits the accessibility of the drug to some cells [58]. By contrast, in 2D culture, the weak interactions between cells [59] (which appear in a diffuse formation) may facilitate the distribution of the drug to cells. Moreover, drug sensitivity variation among 2D and 3D cultures was shown to be cell-type dependent. Our findings revealed that the GIA3D is a potent candidate for cancer drug screening. Furthermore, the 3D culture systems mimic the in vivo environment better than traditional 2D cell culture due to the ability of the cells to form cell-cell interactions and develop into 3D structures in comparison with cell culture in a flat Petri dish [60]. Nevertheless, further experiments are needed to better understand the mechanisms involved in the cytotoxicity of drugs in our 3D scaffolds.

(A)

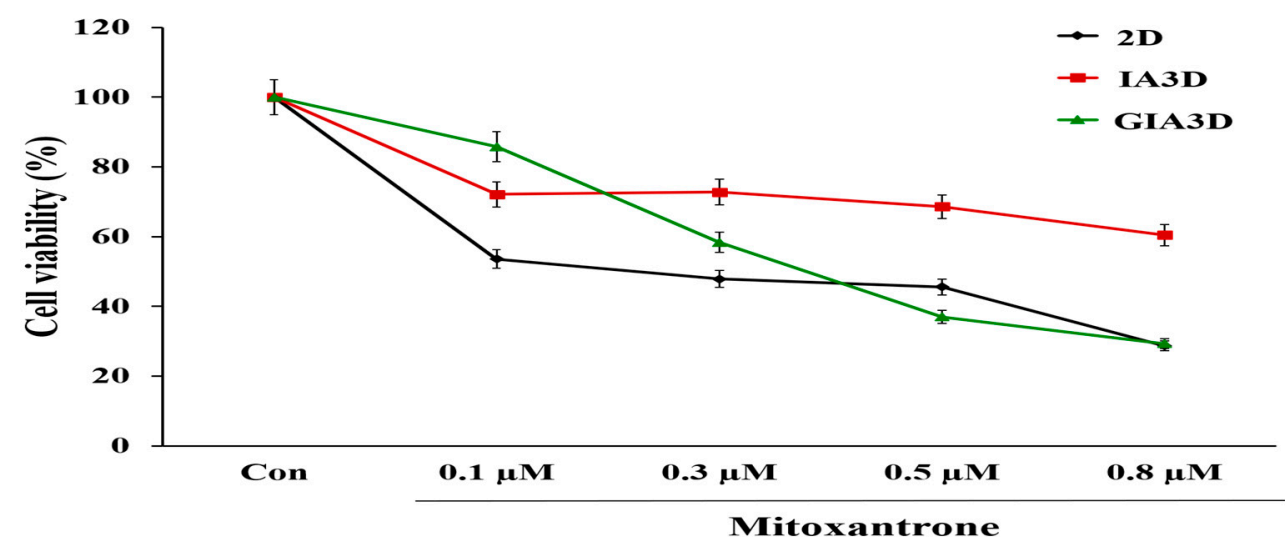

(B)

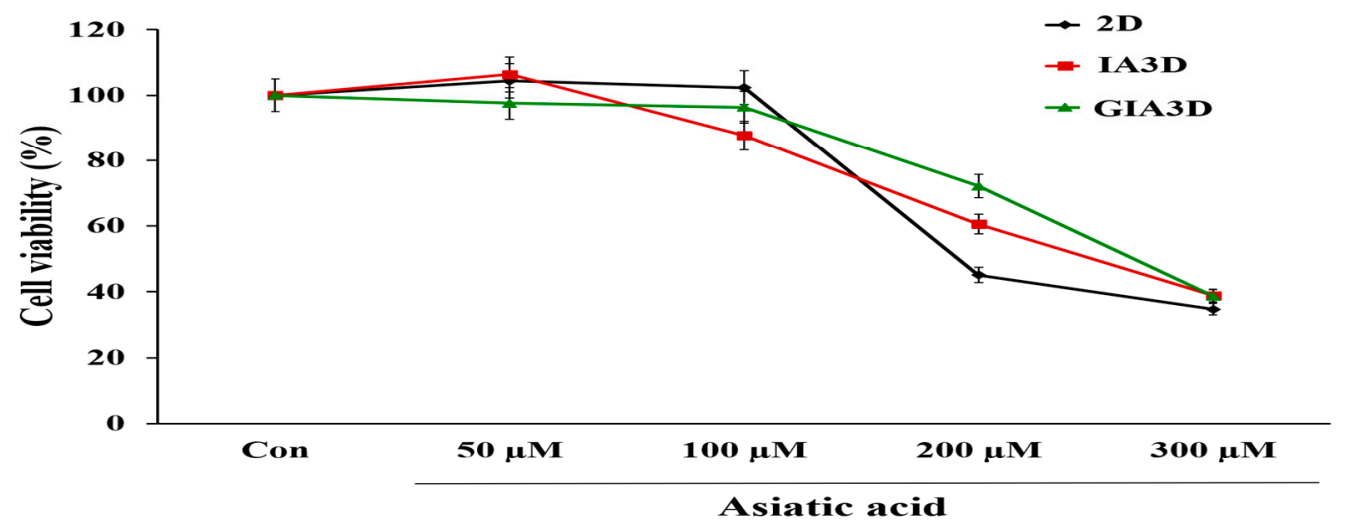

Figure 10. Cytotoxic effects of drugs on HaCaT cells. (A,B) Effects of mitoxantrone and asiatic acid drugs on $\mathrm{HaCaT}$ cells cultured in two-dimensional culture, industrial acrylonitrile butadiene styrene, and gold nanoparticle-coated ABS scaffold. The cells were seeded at $5 \times 10^{4}$ cell $/ \mathrm{mL}$, incubated for $72 \mathrm{~h}$ afterward, treated with mitoxantrone $(0.1-0.8 \mu \mathrm{M})$, or asiatic acid $(50-300 \mu \mathrm{M})$ for $24 \mathrm{~h}$. The relative cell viabilities were calculated as the percentage of untreated cells. Results are expressed as mean $\pm \mathrm{SD}, n=3$.

\section{Conclusions}

To our knowledge, we report for the first time that IA3D can be safely used for stimulating cell proliferation, spheroid formation, and drug screening applications. The experimental conditions were optimized to accelerate the spheroid formation time for the cancer cells HepG2 (in 2 days) and keratinocytes $\mathrm{HaCaT}$ cells (in 3 days). Interestingly, GIA3D increased the number of HepG2 spheroids by 1.3 -fold and reduced the number of apoptotic HaCaT cells (15.3\% in GIA3D versus $31.2 \%$ in IA3D) when compared with IA3D. Additionally, the GIA3D improved cell proliferation and highly reduced the sensitivity of HepG2 cells to mitoxantrone and asiatic acid drugs when compared with IA3D and $2 \mathrm{D}$ culture. These results indicated that the proposed 3D structures could potentially be used as a 
diagnostic system, anticancer evaluation, and cosmetic testing application or can be utilized to prolong various cell functions in culture. Thus, our results suggest that this cost-effective and attractive 3D scaffold may be used in vitro for cellular biology studies and drug screening applications to mimic in vivo phenomena.

Author Contributions: Conceptualization, J.H.A. and K.-J.L.; investigation, K.P.U.N. and G.-J.K.; validation, K.-J.L. and J.H.A.; visualization K.-H.C., J.-S.S., K.-S.L. and J.-W.C.; original draft of manuscript, K.P.U.N., G.-J.K. and J.H.A; writing - review and editing, K.P.U.N., G.-J.K., K.-J.L and J.H.A. All authors have read and agreed to the published version of the manuscript.

Funding: This work was as supported by the Basic Science Research Program through the National Research Foundation of Korea (NRF-2016R1D1A1B04935060 and NRF-2018R1D1A1B07048282).

Conflicts of Interest: The authors declare no conflict of interest.

\section{References}

1. Wu, J.; Xie, L.; Lin, W.Z.Y.; Chen, Q. Biomimetic nanofibrous scaffolds for neural tissue engineering and drug development. Drug Discov. Today 2017, 22, 1375-1384. [CrossRef]

2. Bottino, M.C.; Yassen, G.H.; Platt, J.A.; Labban, N.; Windsor, L.J.; Spolnik, K.J.; Bressiani, A.H. A novel three-dimensional scaffold for regenerative endodontics: materials and biological characterizations. J. Tissue Eng. Regen. Med. 2015, 9, 116-123. [CrossRef] [PubMed]

3. Nguyen., A.H.; Marsh, P.; Schmiess-Heine, L.; Burke, P.J.; Lee, A.; Lee, J.; Cao, H. Cardiac tissue engineering: state-of-the-art methods and outlook. J. Biol. Eng. 2019, 13, 57. [CrossRef] [PubMed]

4. Geetha, B.R.; Muthoosamy, K.; Manickam, S.; Hilal-Alnaqbi, A. Graphene-based 3D scaffolds in tissue engineering: fabrication, applications, and future scope in liver tissue engineering. Int. J. Nanomed. 2019, 14, 5753-5783. [CrossRef] [PubMed]

5. Institute of Medicine. Improving and Accelerating Therapeutic Development for Nervous System Disorders: Workshop Summary, 2 Drug Development Challenges; The National Academies Press: Washington, DC, USA, 2014.

6. Joseph, J.S.; Malindisa, S.T.; Ntwasa, M. Two-Dimensional (2D) and Three-Dimensional (3D) Cell Culturing in Drug Discovery. In Cell Culture; Radwa, A.M., Ed.; IntechOpen: London, UK, 2018.

7. Ingle, A.D. Alternatives and Refinement for Animal Experimentation in Cancer Research. In Alternatives to Animal Testing; Kojima, H., Seidle, T., Spielmann, H., Eds.; Springer: Singapore, 2019; pp. 69-75.

8. Joshi, P.N. Cell and Organs on Chip-A Revolutionary Platform for Biomedicine. In Lab-on-a-Chip Fabrication and Application; Stoytcheva, M., Zlatev, R., Eds.; IntechOpen: London, UK, 2016.

9. Rosenzweig, D.H.; Carelli, E.; Steffen, T.; Jarzem, P.; Haglund, L. 3D-printed ABS and PLA scaffolds for cartilage and nucleus pulposus tissue regeneration. Int. J. Mol. Sci. 2015, 16, 15118-15135. [CrossRef] [PubMed]

10. Cai, H.; Azangwe, G.; Shepherd, D.E. Skin cell culture on an ear-shaped scaffold created by fused deposition modelling. Biomed. Mater. Eng. 2005, 15, 375-380. [PubMed]

11. Hott, M.E.; Megerian, C.A.; Beane, R.; Bonassar, L.J. Fabrication of tissue engineered tympanic membrane patches using computer-aided design and injection molding. Laryngoscope 2004, 114, 1290-1295. [CrossRef] [PubMed]

12. Helguero, C.G.; Mustahsan, V.M.; Parmar, S.; Pentyala, S.; Pfail, J.P.; Kao, I.; Komatsu, D.; Pentyala, S. Biomechanical properties of 3D-printed bone scaffolds are improved by treatment with CRFP. J. Orthop. Surg. Res. 2017, 12, 195. [CrossRef]

13. Dul, S.; Fambri, L.; Pegoretti, A. Filaments production and fused deposition modelling of ABS/carbon nanotubes composites. Nanomaterials (Basel) 2018, 8, 49.

14. Campbell, T.A.; Ivanova, O.S. 3D printing of multifunctional nanocomposites. Nano Today 2013, 8, 119-120. [CrossRef]

15. Khan, M.A.; Cantù, E.; Tonello, S.; Serpelloni, M.; Lopomo, N.F.; Sardini, E. A review on biomaterials for 3D conductive scaffolds for stimulating and monitoring cellular activities. Appl. Sci. 2019, 9, 961. [CrossRef]

16. Shevach, M.; Maoz, B.M.; Feiner, R.; Shapira, A.; Dvi, T. Nanoengineering gold particle composite fibers for cardiac tissue engineering. J. Mater. Chem. B 2013, 1, 5210-5217. [CrossRef]

17. Karakoçak, B.B.; Raliya, R.; Davis, J.T.; Chavalmane, S.; Wang, W.N.; Ravi, N.; Biswas, P. Biocompatibility of gold nanoparticles in retinal pigment epithelial cell line. Toxicol. Vitro 2016, 37, 61-69. [CrossRef] [PubMed] 
18. Baranes, K.; Shevach, M.; Shefi, O.; Dvir, T. Gold nanoparticle-decorated scaffolds promote neuronal differentiation and maturation. Nano Lett. 2016, 16, 2916-2920. [CrossRef]

19. Fleischer, S.; Shevach, M.; Feiner, R.; Dvir, T. Coiled fiber scaffolds embedded with gold nanoparticles improve the performance of engineered cardiac tissues. Nanoscale 2014, 6, 9410-9414. [CrossRef]

20. Dey, A.; Yodo, N. A systematic survey of FDM process parameter optimization and their influence on part characteristics. J. Manuf. Mater. Process. 2019, 3, 64. [CrossRef]

21. Haeri, M.; Haeri, M. Image j plugin for analysis of porous scaffolds used in tissue engineering. J. Open Res. Softw. 2015, 3, e1. [CrossRef]

22. Mohanty, S.; Larsen, L.B.; Trifol, J.; Szabo, P.; Burri, H.V.R.; Canali, C.; Dufva, M.; Emnéus, J.; Wolff, A. Fabrication of scalable and structured tissue engineering scaffolds using water dissolvable sacrificial 3D printed moulds. Mater. Sci. Eng. C 2015, 55, 569-578. [CrossRef]

23. Turkevich, J.; Stevenson, P.C.; Hillier, J. A study of the nucleation and growth processes in the synthesis of colloidal gold. Discuss. Faraday Soc. 1951, 11, 55-75. [CrossRef]

24. Turkevich, J. Colloidal gold. Part II-Colour, coagulation, adhesion, alloying and catalytic properties. Gold Bull. 1985, 18, 125. [CrossRef]

25. Frens, G. Controlled nucleation for the regulation of the particle size in monodisperse gold suspensions. Nat. Phys. Sci. 1973, 241, 20-22. [CrossRef]

26. Zhang, L.; Yang, G.; Johnson, B.N.; Jia, X. Three-dimensional (3D) printed scaffold and material selection for bone repair. Acta Biomater. 2019, 84, 16-33. [CrossRef] [PubMed]

27. Murphy, C.M.; O'Brien, F.J. Understanding the effect of mean pore size on cell activity in collagenglycosaminoglycan scaffolds. Cell Adh. Migr. 2010, 4, 377-381. [CrossRef] [PubMed]

28. Murphy, C.M.; Haugh, M.G.; O’Brien, F.J. The effect of mean pore size on cell attachment, proliferation and migration in collagen-glycosaminoglycan scaffolds for tissue engineering. Biomaterials 2010, 31, 461-466. [CrossRef] [PubMed]

29. Bružauskaitė, I.; Bironaitė, D.; Bagdonas, E.; Bernotienė, E. Scaffolds and cells for tissue regeneration: different scaffold pore sizes-different cell effects. Cytotechnology 2016, 68, 355-369. [CrossRef]

30. Nava, M.M.; Draghi, L.; Giordano, C.; Pietrabissa, R. The effect of scaffold pore size in cartilage tissue engineering. J. Appl. Biomater. Funct. Mater. 2016, 14, 223-229. [CrossRef]

31. Loh, Q.L.; Choong, C. Three-dimensional scaffolds for tissue engineering applications: role of porosity and pore size. Tissue Eng. Part B Rev. 2013, 19, 485-502. [CrossRef]

32. Milionis, A.; Noyes, C.; Loth, E.; Bayer, I.S.; Lichtenberger, A.W.; Stathopoulos, V.N.; Vourdas, N. Waterrepellent approaches for 3-D printed internal passages. Mater. Manuf. Process. 2016, 31, 1162-1170. [CrossRef]

33. Gregor, A.; Filova, E.; Novak, M.; Kronek, J.; Chlup, H.; Buzgo, M.; Blahnová, V.; Lukášová, V.; Bartoš, M.; Nečas, A.; et al. Designing of PLA scaffolds for bone tissue replacement fabricated by ordinary commercial 3D printer. J. Biol. Eng. 2017, 11, 31. [CrossRef]

34. Yang, F.; Chen, C.; Zhou, Q.; Gong, Y.; Li, R.; Li, C.; Klämpfl, F.; Freund, S.; Wu, X.; Sun, Y.; et al. Laser beam melting 3D printing of Ti6Al4V based porous structured dental implants: fabrication, biocompatibility analysis and photoelastic study. Sci. Rep. 2017, 7, 45360. [CrossRef]

35. Kellomäki, M.; Laine, K.; Ellä, V.; Annala, T. Bioabsorbable fabrics for musculoskeletal scaffolds. In Biomedical Textiles for Orthopaedic and Surgical Applications: Fundamentals, Applications and Tissue Engineering, 2nd ed.; Blair, T., Ed.; Elsevier: Amsterdam, The Netherlands, 2015; pp. 67-90.

36. Kramschuster, A.; Turng, L.S. Fabrication of tissue engineering scaffolds. In Handbook of Biopolymers and Biodegradable Plastics: Properties, Processing and Applications, 2nd ed.; Ebnesajjad, S., Ed.; Elsevier Inc.: San Diego, CA, USA, 2013; pp. 427-446.

37. Rabionet, M.; Polonio, E.; Guerra, A.J.; Martin, J.; Puig, T.; Ciurana, J. Design of a scaffold parameter selection system with additive manufacturing for a biomedical cell culture. Materials 2018, 11, 1427. [CrossRef] [PubMed]

38. Li, C.; Li, D.; Wan, G.; Xu, J.; Hou, W. Facile synthesis of concentrated gold nanoparticles with low size-distribution in water: Temperature and pH controls. Nanoscale Res. Lett. 2011, 6, 440. [CrossRef] [PubMed]

39. Tran, M.; DePenning, R.; Turner, M.; Padalkar, S. Effect of citrate ratio and temperature on gold nanoparticle size and morphology. Mater. Res. Express 2016, 3, 105027. [CrossRef]

40. Njoki, P.N.; Lim, I.-I.S.; Mott, D.; Park, H.-Y.; Khan, B.; Mishra, S.; Sujakumar, R.; Luo, J.; Zhong, C.-J. Size correlation of optical and spectroscopic properties for gold nanoparticles. J. Phys. Chem. C 2007, 111, 14664-14669. [CrossRef] 
41. Mohan, J.C.; Praveen, G.; Chennazhi, K.P.; Jayakumar, R.; Nair, S.V. Functionalised gold nanoparticles for selective induction of in vitro apoptosis among human cancer cell lines. J. Exp. Nanosci. 2013, 8, 32-45. [CrossRef]

42. Casavola, C.; Cazzato, A.; Moramarco, V.; Pappalettere, C. Orthotropic mechanical properties of fused deposition modelling parts described by classical laminate theory. Mater. Des. 2016, 90, 453-458. [CrossRef]

43. Ceretti, E.; Ginestra, P.; Neto, P.I.; Fiorentino, A.; Da Silva, J.V.L. Multi-layered scaffolds production via fused deposition modeling (FDM) using an open source 3D printer: process parameters optimization for dimensional accuracy and design reproducibility. Procedia CIRP 2017, 65, 13-18. [CrossRef]

44. Novakova-Marcincinova, L.; Kuric, I. Basic and advanced materials for fused deposition modeling rapid prototyping technology. Manuf. Ind. Eng. 2012, 11, 24-27.

45. Rosman, C.; Pierrat, S.; Tarantola, M.; Schneider, D.; Sunnick, E.; Janshoff, A.; Sönnichsen, C. Mammalian cell growth on gold nanoparticle-decorated substrates is influenced by the nanoparticle coating. Beilstein J. Nanotechnol. 2014, 5, 2479-2488. [CrossRef]

46. Zeng, Q.; Shao, D.; Ji, W.; Li, J.; Chen, L.; Song, J. The nanotoxicity investigation of optical nanoparticles to cultured cells in vitro. Toxicol. Rep. 2014, 1, 137-144. [CrossRef]

47. Huang, K.; Ma, H.; Liu, J.; Huo, S.; Kumar, A.; Wei, T.; Zhang, X.; Jin, S.; Gan, Y.; Wang, P.C.; et al. Size-dependent localization and penetration of ultrasmall gold nanoparticles in cancer cells, multicellular spheroids, and tumors in vivo. ACS. Nano 2012, 6, 4483-4493. [CrossRef] [PubMed]

48. Pavlovich, E.; Volkova, N.; Yakymchuk, E.; Perepelitsyna, O.; Sydorenko, M.; Goltsev, A. In vitro study of influence of Au nanoparticles on HT29 and SPEV cell lines. Nanoscale Res. Lett. 2017, 12, 494. [CrossRef] [PubMed]

49. Chandrasekaran, S.; Giang, U.B.; King, M.R.; DeLouise, L.A. Microenvironment induced spheroid to sheeting transition of immortalized human keratinocytes (HaCaT) cultured in microbubbles formed in polydimethylsiloxane. Biomaterials 2011, 32, 7159-7168. [CrossRef] [PubMed]

50. Breslin, S.; O'Driscoll, L. The relevance of using 3D cell cultures, in addition to 2D monolayer cultures, when evaluating breast cancer drug sensitivity and resistance. Oncotarget 2016, 7, 45745-45756. [CrossRef] [PubMed]

51. Lin, R.Z.; Chang, H.Y. Recent advances in threedimensional multicellular spheroid culture for biomedical research. Biotechnol. J. 2008, 3, 1172-1184.

52. Rabionet, M.; Yeste, M.; Puig, T.; Ciurana, J. Electrospinning PCL scaffolds manufacture for three-dimensional breast cancer cell culture. Polymers (Basel) 2017, 9, 328. [CrossRef]

53. Luca, A.C.; Mersch, S.; Deenen, R.; Schmidt, S.; Messner, I.; Schäfer, K.L.; Baldus, S.E.; Huckenbeck, W.; Piekorz, R.P.; Knoefel, W.T.; et al. Impact of the 3D microenvironment on phenotype, gene expression, and EGFR inhibition of colorectal cancer cell lines. PLoS ONE 2013, 8, e59689. [CrossRef]

54. Luo, L.X.; Fan, X.X.; Li, Y.; Peng, X.; Ji, Y.C.; Hsiao, W.W.; Liu, L.; Leung, E.L.; Yao, X.J. Identification of mitoxantrone as a new inhibitor of ROS1 fusion protein in non-small cell lung cancer cells. Medchemcomm 2017, 8, 621-624. [CrossRef]

55. Xie, B.; He, X.; Guo, G.; Zhang, X.; Li, J.; Liu, J.; Lin, Y. High-throughput screening identified mitoxantrone to induce death of hepatocellular carcinoma cells with autophagy involvement. Biochem. Biophys. Res. Commun. 2020, 521, 232-237. [CrossRef]

56. Lu, Y.; Liu, S.; Wang, Y.; Wang, D.; Gao, J.; Zhu, L. Asiatic acid uncouples respiration in isolated mouse liver mitochondria and induces HepG2 cells death. Eur. J. Pharmacol. 2016, 786, 212-223. [CrossRef]

57. Nagoor Meeran, M.F.; Goyal, S.N.; Suchal, K.; Sharma, C.; Patil, C.R.; Ojha, S.K. Pharmacological properties, molecular mechanisms, and pharmaceutical development of asiatic acid: a pentacyclic triterpenoid of therapeutic promise. Front. Pharmacol. 2018, 9, 892. [CrossRef]

58. Hickman, J.A.; Graeser, R.; de Hoogt, R.; Vidic, S.; Brito, C.; Gutekunst, M.; van der Kuip, H.; IMI PREDECT Consortium. Three-dimensional models of cancer for pharmacology and cancer cell biology: capturing tumor complexity in vitro/ex vivo. Biotechnol. J. 2014, 9, 1115-1128. [CrossRef] [PubMed]

59. Mirbagheri, M.; Adibnia, V.; Hughes, B.R.; Waldman, S.D.; Banquy, X.; Hwang, D.K. Advanced cell culture platforms: A growing quest for emulating natural tissues. Mater. Horiz. 2018, 6, 45-71. [CrossRef]

60. Hoarau-Véchot, J.; Rafii, A.; Touboul, C.; Pasquier, J. Halfway between 2D and animal models: Are 3D cultures the ideal tool to study cancer-microenvironment interactions? Int. J. Mol. Sci. 2018, 19, 181. [CrossRef] [PubMed]

(C) 2020 by the authors. Licensee MDPI, Basel, Switzerland. This article is an open access article distributed under the terms and conditions of the Creative Commons Attribution (CC BY) license (http://creativecommons.org/licenses/by/4.0/). 